NBER WORKING PAPER SERIES

\author{
THE SPECIE STANDARD AS A \\ CONTINGENT RULE: \\ SOME EVIDENCE FOR CORE AND \\ PERIPHERAL COUNTRIES, 1880-1990
}

Michael D. Bordo

Anna J. Schwartz

Working Paper No. 4860

\author{
NATIONAL BUREAU OF ECONOMIC RESEARCH \\ 1050 Massachusetts Avenue \\ Cambridge, MA 02138 \\ September 1994
}

This paper is part of NBER's research programs in the Development of the American Economy and Monetary Economics. Any opinions expressed are those of the authors and not those of the National Bureau of Economic Research.

() 1994 by Michael D. Bordo and Anna J. Schwartz. All rights reserved. Short sections of text, not to exceed two paragraphs, may be quoted without explicit permission provided that full credit, including $(\mathcal{O}$ notice, is given to the source. 


\title{
THE SPECIE STANDARD AS A \\ CONTINGENT RULE: \\ SOME EVIDENCE FOR CORE AND \\ PERIPHERAL COUNTRIES, 1880-1990
}

\begin{abstract}
The specie standard that prevailed before 1914 was a contingent rule. Under the rule specie convertibility could be suspended in the event of a well understood, exogenously produced emergency, such as a war, on the understanding that after the emergency had safely passed convertibility would be restored at the original parity. Market agents would regard successful adherence as evidence of a credible commitment and would allow the authorities access to seigniorage and bond finance at favorable terms.

This paper surveys the history of the specie standard as a contingent rule for 21 countries divided into core and peripheral countries. As a comparison we also briefly consider the Bretton Woods system and the recent managed floating regime.

We offer some evidence on capital flows 1865 to 1914 from England to two countries of recent settlement -- Argentina and the United States -- during episodes of both suspension and adherence to convertibility. It suggests that adherence to the rule may have had some influence on the decision by England to invest abroad.

We then present evidence across four regimes (pre-1914 gold standard; interwar gold standard; Bretton Woods; the subsequent managed exchange rate float) for the 21 countries on the stability of macro variables as well as on demand shocks (reflecting policy actions specific to the regime) and supply shocks (reflecting shocks to the environment independent of the regime). These measures allow us to determine whether adherents to the rule consistently pursued different policy actions from nonadherents, and whether persistent adverse shocks to the environment may, for some countries, have precluded adherence to the rule.
\end{abstract}

Michael D. Bordo Department of Economics Rutgers University New Brunswick, NJ 08903 and NBER
Anna J. Schwartz

National Bureau of Economic Research 269 Mercer Street, 8th Floor New York, NY 10003 
THE SPECIE STANDARD AS A CONTINGENT RULE: SOME EVIDENCE FOR CORE AND PERIPHERAL COUNTRIES, 1880-1990

\section{Introduction}

The classical gold standard era from 1880 to 1914, when most countries of the world defined their currencies in terms of a fixed weight (which is equivalent to a fixed price) of gold and hence adhered to a fixed exchange rate standard, has been regarded by many observers as a most admirable monetary regime. They find that its benefits include long-run price level stability and predictability, stable and low long-run interest rates, stable exchange rates (McKinnon, 1988), and hence that it facilitated a massive flow of capital from the advanced countries of Europe to the world's developing countries.

Others have taken a less favorable view of the gold standard's performance. Some criticize the record of relatively high real output and short-term price variability (Bordo, 1981; Cooper, 1982; Meltzer and Robinson, 1989), and some have faulted it for subordinating domestic stability to the maintenance of external convertibility (Keynes, 1930).

A persistent critique of the gold standard is that it provided a favorable experience for the core countries (England, France, Germany, and the United States), but a less favorable experience for the peripheral countries of the developing world (De Cecco, 1974). For the core countries the balance of payments adjustment mechanism was stable, so few crises occurred; the peripheral countries, by contrast, were subject to shocks imported under fixed exchange rates from abroad and frequently suffered exchange rate crises and a destabilized growth pattern.

An alternative approach to these issues of gold standard history posits that adherence to the fixed price of specie, which characterized all convertible metallic regimes including the gold standard, served as a credible commitment mechanism to monetary and fiscal policies that otherwise would be time inconsistent (Bordo and Kydland, 1992; Giovannini, 1993). On this basis, adherence to the specie standard rule enabled many countries to avoid the problems of high inflation and stagflation that troubled the late twentieth century. The specie standard that prevailed before 1914 was a contingent rule, or a rule with escape clauses. Under the rule specie convertibility could be suspended in the event of a well understood, exogenously produced emergency, such as a war, on the understanding that after the emergency had safely passed convertibility would be restored at the original parity. Market agents would 
regard successful adherence as evidence of a credible commitment and would allow the authorities access to seigniorage and bond finance at favorable terms.

On this view, the core countries were good players of the classical gold standard game - they adhered strictly to the rule, whereas many peripheral countries were not. Some never adhered to the rule. Others joined it when conditions were favorable to them ostensibly to obtain access to capital from the core countries, but they quickly abandoned it when economic conditions deteriorated.

The interwar gold standard can be regarded as an extension of the pre-1914 system because it was based on gold converibility. However, it was less successful because the commitment to convertibility was often subordinated to other politically induced objectives. The Bretton Woods international monetary system can be regarded as a distant relative of the classical gold standard in that the center country, the United States, maintained gold convertibility. It was also based on a rule with an escape clause - parities could be changed in the event of a fundamental disequilibrium. However, it differed from the basic specie standard rule in that a credible commitment to the fixed parity was not of such primary importance.

This paper surveys the history of the specie standard as a contingent rule from the early nineteenth century when most countries were still on a bimetallic or silver standard until the gold standard's final collapse in the late 1930s. As a comparison we also briefly consider the Bretton Woods system and the recent managed floating regime. We then present some evidence on the economic performance of the core and a number of peripheral countries under the various regimes.

Section 2 defines the contingent specie standard rule and discusses how the commitment to convertibility was maintained. Section 3 presents and discusses a chronology of adherence to the rule by 21 countries under variants of the specie standard prevailing before World War II. A similar chronology is included for the Bretton Woods system. Section 4 offers some graphical evidence on capital flows 1865 to 1914 from England to two countries of recent settlement - Argentina and the United States - during episodes of both suspension and adherence to convertibility. It suggests that adherence to the rule may have had some influence on the decision by England to invest abroad.

Section 5 presents evidence on economic performance for 21 countries (both core and peripheral) across several regimes. Such evidence may shed light on whether differing economic performance can 
explain why some countries successfully adhered to the rule and others did not, or whether adherence/nonadherence may have influenced performance. We examine the stability of both nominal and real macro variables across four regimes (pre-1914 gold standard; interwar gold standard; Bretton Woods; the subsequent managed exchange rate float). We then present measures of both demand shocks (reflecting policy actions specific to the regime) and supply shocks (reflecting shocks to the environment independent of the regime). These measures allow us to determine whether adherents to the rule consistently pursued different policy actions from nonadherents, and whether persistent adverse shocks to the environment may, for some countries, have precluded adherence to the rule. The paper concludes with answers to the questions: how successful was the specie standard rule as a contingent rule; why it was successful when it was; and why some countries adhered while others did not.

\section{The Specie Standard as a Contingent Rule}

\subsection{The Domestic Gold Standard}

A specie standard has been traditionally viewed as a form of monetary rule or constraint over monetary policy actions. Following a rule, such as adherence to the specie standard, which would cause the money suppiy to vary automatically with the balance of payments, was viewed as superior to entrusting policy to the discretion of well-meaning and possibly well-informed monetary authorities (Simons, 1951).' In contrast to the traditional view, which stresses both impersonality and automaticity, the recent literature on the time inconsistency of optimal government policy regards a rule as a credible commitment mechanism binding policy actions over time.

The absence of a credible commitment mechanism leads governments, in pursuing stabilization policies, to produce an inflationary outcome (Kydland and Prescott, (1977); Barto and Gordon, (1983). In a closed economy environment, once the monetary authority has announced a given rate of monetary growth, which the public expects it to validate, the authority then has an incentive to create a monetary surprise to either reduce unemployment or capture seigniorage revenue. The public, with rational expectations, will come to anticipate the authorities' perfidy, leading to an inflationary equilibrium. A credible precommitment mechanism, by preventing the government from cheating, can preserve long-run price stability. 
Following a rule also allows a government to use debt to smooth distortionary taxes

over time. In addition to choosing optimal taxes the government can also choose an optimal default rate on its outstanding debt. In a commitment regime the government can force itself to honor its outstanding debt and not default via inflation or suspension of payments. If the government cannot follow a binding commitment -- in other words, if it follows a discretionary regime -- rational bond holders would expect the government to have an incentive to default on its outstanding debt. Hence, in a discretionary equilibrium bond holders will be averse to purchasing government debt.

Under the specie standard, the pledge to fix the price of a country's currency in terms of gold, silver, or both, represents the basic rule. This involved e.g. in the case of a monometallic gold standard, defining a gold coin as a fixed weight of gold, called for example, one dollar. The monetary authority was then committed to keep the mint price of gold fixed through the purchase and sale of gold in unlimited amounts. Under the bimetallic system which prevailed in most countries until the third quarer of the nineteenth century, the monetary authorities would define the weight of both gold and silver coins, freely buying and selling them. Maintaining the bimetallic ratio fixed is a variant of the basic convertibility rule, since it is the fixed value of the unit of account that is the essence of the rule. ${ }^{2}$

The specie standard rule followed in the century before World War I can be viewed as a form of contingent rule or rule with escape clauses (Grossman and Van Huyck, 1988; DeKock and Grilli, 1989; Flood and Isard, 1989; Bordo and Kydland, 1992). The monetary authority maintains the standard - keeps the price of the currency in terms of specie fixed - except in the event of a well understood emergency such as a major war. In wartime it may suspend gold convertibility and issue paper money to finance its expenditures, and it can sell debt issues in terms of the nominal value of its currency, on the understanding that debt will eventually be paid off in specie. The rule is contingent in the sense that the public understands that the suspension will only last for the duration of the wartime emergency plus some period of adjustment. It assumes that afterwards the government will follow the deflationary policies necessary to resume payments at the original parity. ${ }^{3}$ Following such a rule will allow the government to smooth its revenue from different sources of finance: taxation, borrowing, and seigniorage (Lucas and Stokey, 1983; Mankiw, 1987). 
As we document in Section 3, the gold standard contingent rule worked successfully for three core countries of the classical gold standard: Britain, France, and the U.S. In all these countries the monetary authorities adhered faithfully to the fixed price of gold except during major wars. During the Napoleonic War and World War I for England, the Civil War for the U.S., and the Franco-Prussian War for France, specie payments were suspended, paper money and debt were issued. But in each case, after the wartime emergency had passed, policies leading to resumption were adopted.' Indeed, successful adherence to the rule may have enabled the belligerents to obtain access to debt finance more easily in subsequent wars. ${ }^{6}$

Examples of discretion -- breaches of the rule -- include postponement of resumption after the war and reasonable delay period have passed, and pegging to specie at a devalued parity. Under both situations, should there be another war within memory of the previous one, then the public's behavior in being willing to absorb government debt would be quite different from that in the previous war, even if the situation is otherwise similar and the government claims to subscribe to a reasonable delay rule.

It is crucial that the rule be transparent and simple and that only a limited number of contingencies be included. Transparency and simplicity would avoid the problems of moral hazard and incomplete information (Canzoneri, 1985; Obstfeld, 1992), i.e. prevent the monetary authorities' from engaging in discretionary policy under the guise of following the contingent rule. In this respect a second contingency -- a temporary suspension in the face of a financial crisis, which in turn was not the result of the monetary authorities' own actions, may also have been part of the rule. However, because of the greater difficulty of verifying the source of the contingency than in the case of war - invoking the escape clause under conditions of financial crisis, or in the case of a shock to the terms of trade (a third possible contingency) would be more likely to create suspicion that discretion was being followed.

The specie standard rule may have been enforced by reputational considerations. Long-run adherence to the rule was based on the historical evolution itself of the standard, thus e.g. gold was accepred as money because of its intrinsic value and desirable properties. Paper claims, developed to economize on the scarce resources tied up in a commodity money, became acceptable only because they were convertible into gold. 
In turn, the reputation of the specie standard would constrain the monetary authorities from breaching convertibility, except under well-understood contingencies. Thus, when an emergency occurred, the abandonment of the standard would be viewed by all to be a temporary event since, from their experience, only specie or specie-backed claims truly served as money. An alternative commitment mechanism was to guarantee gold convertibility in the constitution. This was the case for example in Sweden before 1914, when laws pertaining to the gold standard could be changed only by two identical parliamentary decisions with an election in between (Jonung, 1984, p. 368). Convertibility was also enshrined in the laws of a number of gold standard central banks (Giovannini, 1993).

\subsection{The International Gold Standard}

The specie standard rule originally evolved as a domestic commitment mechanism but its enduring fame is as an international rule. The classical gold standard emerged as a true international standard by 1880 following the switch by the majority of countries from bimetallism, silver monometalism, and paper to gold as the basis of their currencies, (Eichengreen 1985). As an international standard, the key rule was maintenance of gold convertibility at the established par. Maintenance of a fixed price of gold by its adherents in turn ensured fixed exchange rates. The fixed price of domestic currency in terms of gold provided a nominal anchor to the international monetary system.

Recent evidence suggests that, indeed, exchange rates throughout the 1880 to 1914 period were characterized by a high degree of fixity in the principal countries. Although exchange rates frequently deviated from par, violations of the gold points were rare (Officer, 1986), as were devaluations (Eichengreen, 1985).

According to the game theoretic literature, for an international monetary arrangement to be effective both between countries and within them, a time consistent credible commitment mechanism is required (Canzoneri and Henderson, 1991). Adherence to the gold convertibility rule provided such a mechanism. Indeed, Giovannini (1993) finds the variation of both exchange rates and short-term interest rates within the limits set by the gold points in the $1899-1909$ period consistent with market agents' expectations of a credible commitment by the "core" countries to the gold-standard rule in the sense of this paper.' In addition to the reputation of the domestic gold standard and constitutional provisions 
which ensured domestic commitment, adherence to the international gold-standard rule may have been enforced by other mechanisms. These include: improved access to international capital markets; the operation of the rules of the game; the hegemonic power of England; and central bank cooperation.

Support for the international gold standard likely grew because it provided improved access to the international capital markets of the core countries. Countries were eager to adhere to the standard because they believed that gold convertibility would be a signal to creditors of sound government finance and the future ability to service debt. ${ }^{8}$

This was the case both for developing countries seeking access to long-term capital, such as Austria-Hungary (Yeager, 1984) and Latin America (Fishlow, 1989), and for countries seeking short-term loans, such as Japan, which financed the Russo-Japanese war of 1905-1906 with foreign loans seven years after joining the gold standard (Hayashi, 1989). Once on the gold standard, these countries feared the consequences of suspension (Eichengreen, 1992a, p.19; Fishlow 1987, 1989). The fact that England, the most successful country of the nineteenth century, as well as other "progressive" countries were on the gold standard, was probably a powerful argument for joining (Friedman, 1990; Gallarotti, 1993).

The operation of the "rules of the game," whereby the monetary authorities were supposed to alter the discount rate to speed up the adjustment to a change in external balance, may also have been an important part the commitment mechanism played under the international gold-standard rule. To the extent the "rules" were followed and adjustment facilitated, the commitment to convertibility was strengthened and conditions conducive to abandonment were lessened.

Evidence on the operation of the "rules of the game" questions their validity. Bloomfield (1959), in a classic study, showed that, with the principal exception of England, the rules were frequently violated in the sense that discount rates were not always changed in the required direction (or by sufficient amounts) and in the sense that changes in domestic credit were often negatively correlated with changes in gold reserves. In addition, a number of countries used gold devices - practices to prevent gold outflows.

One can reconcile the violation of the 'rules of the game' and the use of gold devices, with maintenance of credibility in the commitment to gold, by viewing the gold points as a form of target zone 
(Eichengreen, 1994). Belief that intervention would occur at the upper and lower gold points created a honeymoon effect whereby stabilizing capital flows caused the market exchange rate to revert towards parity before reaching the gold points (Krugman, 1991). Within the zone, the monetary authorities could alter discount rates to affect domestic objectives such as stabilizing real activity and smoothing interest rates (Svennson, 1994). ${ }^{9}$ Moreover, for the major countries, at least before 1914, such policies were not used extensively enough to threaten the convertibility into gold (Schwartz, 1984).

An additional enforcement mechanism for the international gold-standard rule may have been the hegemonic power of England, the most important gold-standard country (Eichengreen, 1989). A persistent theme in the literanure on the international gold standard is that the classical gold standard of 1880 to 1914 was a British-managed standard (Bordo, 1984). Because London was the center for the world's principal gold, commodities, and capital markets, because of the extensive outstanding sterlingdenominated assets, and because many countries used sterling as an international reserve currency (as a substitute for gold), it is argued that the Bank of England, by manipulating its bank rate, could attract whatever gold it needed and, furthermore, that other central banks would adjust their discount rates accordingly. Thus, the Bank of England could exert a powerful influence on the money supplies and price levels of other gold-standard countries.

The evidence suggests that the Bank did have some influence on other European central banks (Lindert, 1969). Eichengreen (1987) treats the Bank of England as engaged in a leadership role in a Stackelberg strategic game with other central banks as followers. The other central banks accepted a passive role because of the benefits to them of using sterling as a reserve asset. According to this interpretation, the gold-standard rule may have been enforced by the Bank of England. Thus, the monetary authorities of many countries may have been constrained from following independent discretionary policies that would have threatened adherence to the gold-standard rule.

Indeed, according to Giovannini (1989), the gold standard was an asymmetric system. England was the center country. It used its monetary policy (bank rate) to maintain gold convertibility. Other countries accepted the dictates of fixed parities and allowed their money supplies to passively respond. 
His regressions support this view--the French and German central banks adapted their domestic policies to external conditions, whereas the British did not.

The benefits to England as leader of the gold standard - from seigniorage earned on foreign-held sterling balances, from returns to financial institutions generated by its central position in the gold standard and from access to international capital markets in wartime - were substantial enough to make the costs of not following the rule extremely high.

Finally, Eichengreen (1992b) argues that episodic central bank cooperation may have also strengthened the credibility of the gold standard. Lines of credit arranged between the Banque de France, other central banks and the Bank of England during incipient financial crises such as 1890 and 1907 may in turn have encouraged private stabilizing capital movements to offset threats to convertibility.

\subsection{The Classical Gold Standard, the Gold Exchange Standard and Bretton Woods}

Eichengreen (1994) posits three prequisites for a successful international monetary artangement: the capacity to undertake relative price adjustment; adherence to robust monetary rules; and ability to contain market pressures. According to him the classical gold standard contingent rule satisfied these criteria for the core countries because the credible commitment to maintain convertibility above all else, allowed the escape clause to accommodate major shocks, and because central bank cooperation eased market pressures in the face of speculative attacks. By contrast, for peripheral countries, the credibility of commitment to the gold standard was considerably weaker reflecting strong domestic political pressures to alter exchange rates (Frieden, 1993).

Though gold convertibility was restored by 1926 by most countries, the interwar gold exchange standard was a much less successful application of the specie standard rule. The escape clause could not be invoked (lest it lead to destabilizing capital outflows), absent a credible commitment to maintain gold parity in the face of a politicized money supply process and, according to Eichengreen (1992b), the failure of cooperation.

The Bretton Woods international monetary system can also be viewed within the context of the specie standard rule, although it is a distant variant of the original specie standard. Under the rules of Bretton Woods, only the U.S., as central reserve country and provider of the nominal anchor, was 
required to peg its currency to gold; the other members were required to peg their currencies to the dollar (McKinnon, 1993). They also were encouraged to use domestic stabilization policy to offset temporary disturbances. The Bretton Woods system had an escape clause for its members - a change in parity was allowed in the face of a fundamental disequilibrium, which could encompass the contingencies under the specie standard rule -- but it was not the same as under the specie standard because it did not require restoring the original parity. ${ }^{10}$ The rule for members (other than the U.S.) was enforced, as under the gold standard, by access to U.S. capital and to the IMF's resources. For the U.S., there was no explicit enforcement mechanism other than reputation and the commitment to gold convertibility. Capital controls were viewed as a method to contain market pressures.

The system was successful as long as the U.S. maintained its commitment to convertibility (i.e. maintained price stability). But the escape clause mechanism quickly proved defective since the fundamental disequilibrium contingency was never spelled out and hence parity changes would be accompanied by speculative attacks which became more serious as capital controls became increasingly ineffective. Ultimately, by following highly expansionary monetary and fiscal policies beginning in the mid-1960s, the U.S. attached greater importance to domestic concerns than to its role as the center of the international monetary system, and the system collapsed.

Thus, although the Bretton Woods system can be interpreted as one based on rules, the system did not provide a credible commitment mechanism". The U.S. was unwilling to subsume domestic considerations to the responsibility of maintaining a nominal anchor. At the same time other G-7 countries became increasingly unwilling to follow the dictates of the U.S.-imposed world inflation rate.

\section{Chronology of Adherence to and Suspension of Specie Rules, Pre- and Post-Bretton}

\section{Woods}

\subsection{Design of Table 1}

Table 1 gives a snapshot record of the conformity of 21 countries to specie rules - commitment to a fixed parity with an escape clause. The table is in two segments, segment $A$ referring to the extended period from the nineteenth century through the post-World War I interwar years, when specie 
rules were acknowledged, whether or not observed; segment B referring to the Bretton Woods era, when specie rules were no longer acknowledged or observed (to a limited extent the United States was an exception) but countries submitted to the rule that only in the case of fundamental disequilibrium was a change in parity permissible. Countries did not lightly change par values of their currencies.

The countries are divided into two main groupings, 4 core countries and 17 peripheral countries. Over the extended period covered by segment $A$, core countries were faithful to specie rules under the classical gold standard from 1880 to 1914, but not invariably so in the decades before and after. The peripheral countries, which are classified in the main according to geographical location, were intermittently faithful over the extended period.

Segment A separates experience under a bimetallic or silver standard, which prevailed before the last quarter of the nineteenth century, from experience under the gold standard that followed. For each standard and each country the table shows dates when a commitment was made to convert the national currency into specie, dates of suspension of the commitment, and the reasons for suspension. For the gold standard an additional column indicates whether a change in parity was made on resumption of convertibility after suspension. The column is omitted for bimetallic or silver experience because in these cases we have not established the dates of devaluations or revaluations after resumptions. Segment B dealing with Bretton Woods gives the dates each country (except for Switzerland, which was not a member) declared its par value to the IMF, dates of suspension, if any, dates of change of par value, and reasons for suspension or par change.

\subsection{Evaluating Core Country Adherence to Specie Rules: Segment A}

The four councries (in Part 1 of the table) that we designate as the core include France, Germany, the U.K., and the U.S. We discuss first the record for these countries before they adopted the gold standard. For the bimetallic/silver standard period, there are no entries for Germany, since it was not 
unified until 1871 . The individual German states, however, were on a bimetallic standard, as were also the other three core countries.

1803 is the entry in the table for the date of convertibility of the French franc into gold or silver. A bimetallic system nevertheless predated that entry by centuries, but before 1803, France had endured devaluations, revaluations, John Law's inflationary inconvertible paper money experiment, 1716-20, and the revolutionary war assignat hyperinflation, 1789-95. So 1803 marks the beginning of a stable system, with only two interruptions until 1878, when France switched to gold. The two interruptions were suspensions in 1848-50, following the overthrow of the July monarchy, and 1870-78, following the Franco-German war. Both of these interruptions qualify as consistent with adherence to specie rules, since the suspensions were valid exercises of the escape clauses.

Although the table shows 1694, the year the Bank of England was founded, as the date for convertibility of the British pound into silver, Britain was on a silver standard as far back as the thirteenth century. De facto the country was on a gold standard from 1717 on, owing to the overvaluation of gold by Sir Isaac Newton, the Master of the Mint; de jure the country adopted the gold standard in 1816, while suspension of convertibility was still in effect. There had been banking crises in 1763, 1772, and 1783, but no suspensions until the war with France ended convertibility from 1797 to 1821 . This again we regard not as a breach of the rule but proper invocation of the escape clause not only for the duration of the war but for a period of adjustment thereafter. Resumption at the prewar parity also respects the rule (Bordo and Kydland, 1992).

Whether the United States is eligible for inclusion among core countries in the nineteenth century is the subject of debate. We discuss the issue when we examine the status of the United States under the classical gold standard. Having concluded for the later period that the United States belongs among core countries, we also do not exclude it from the core group when it was on a bimetallic standard. 
The U.S. Coinage Act of 1792 defined the bimetallic standard at a mint ratio of 15 to 1 . In 1834 and again in 1837 the mint ratio was altered, remaining unchanged thereafter at 16 to 1 . Banking panics in 1837 and 1857 led to temporary restriction of payments by banks but no suspension of convertibility. The Civil War, however, occasioned suspension from 1862 through 1878. In 1873 there was a banking panic, like the earlier ones, in which the banks restricted payments of high-powered paper money. Despite contentious political opposition to deflation that resumption enforced, on January 1, 1879 , resumption was achieved at the prewar parity, in line with the declaration of the Resumption Act of 1875 .

Under the classical gold standard both France and Germany observed specie rules until the outbreak of World War 1. Each then suspended convertibility, and both devalued before resuming in the 1920s. Convertibility by France lasted for eight years, by Germany for seven years, and then both devalued after suspending in 1931 . The public probably regarded suspension per se because of war and financial crisis as permissible under the escape clause. The change in parity, however, diluted the credibility of the countries' attachment to specie rules.

The U.K.'s record before World War I is the epitome of proper conduct under the gold standard. As the country at the center of the system, operating with a small gold reserve, it nevertheless managed to serve both its domestic and international interests while maintaining convertibility. Three banking panics in 1847,1857 , and 1866 led to suspension of the Banking Act of 1844, which limited the Bank of England's fiduciary issue, but did no damage to the convertibility commitment. Thereafter the Bank acted to defuse panics before they emerged, as in 1890 and 1907 . Convertibility was abandoned by the Bank in World War I (de facto in 1914 and dejure in 1919), taking advantage of the escape clause, and the rerurn to the gold standard at the prewar parity was delayed until 1925 , also consonant with the provisions of the escape clause. The convertibility commitment, however, lasted only for six years, and devaluation followed. 
The view, alluded to above, that would exclude the United States as a member of the group of core countries, would shift it to the peripheral country group that includes Australia and Canada. That view takes its cue in part from the silver agitation and legislation of 1878 and 1890 that threatened the convertibility of U.S. dollars into gold (Eichengreen, 1992b, 1994; Giovanini, 1993; Grilli, 1990). If lasting damage to U.S. commitment credibility as a result of the threat had resulted, we would concur. Since the threat was a temporary one, and convertibility was never suspended, we conclude that the United States, by the end of the nineteenth century a colossus on the world stage, belongs with the core. Another reason advanced for excluding the United States from the core is that before 1914 it was a net capital importer and hence more like Australia and Canada than the core countries that provided the capital. This is a narrow dimension by which to judge the U.S. relative economic importance. It was wealthier and more populous than the U.K. under the classical gold standard, and certainly than France and Germany. The United States was a capital exporter as well as an importer in the nineteenth century, and by 1914 it was a net capital exporter. These considerations reinforce our conclusion that it is properly a core country.

Apart from the silver threat, convertibility from 1879 to 1914 in the United States was never in doubt. It was preserved even during two banking panics in 1893 and 1907 when banks restricted payments. In World War I the U.S. embargoed gold exports, 1917-19, but did not otherwise attenuate the gold standard. Specie rules were, however, flouted by the devaluation of the dollar in 1933 . The changed parity legislated in 1934 remained in effect until 1971.

The record of commitment by the core countries to specie rules is unblemished under the preWorld War I gold standard. Neither France nor Germany played by those rules during the interwar period, having resumed convertibility with devalued gold content of their currencies. The U.K. reverted to its prewar parity when it resumed convertibility in 1925 but by 1931 devalued and abandoned rules 
for discretion. The U.S. followed the U.K. in devaluing in 1933 and adopted a gold standard in 1934 that diverged in fundamental ways from the pre-World War I standard.

\subsubsection{Evaluating Peripheral Country Adherence to Specie Rules: Part 2. Segment A}

Australia and Canada, the two countries that were settled by the U.K. and were part of the Empire, initially used the British currency system. Silver was the metallic medium in Australia before it adopted the gold standard, but it is not clear that a silver standard prevailed. Convertibility at a fixed Australian price of gold dated from 1852. Despite severe banking problems in the 1890 s, Australiz did not suspend convertibility until July 1915 during World War I. It resumed, along with the U.K. in 1925 , at its prewar parity, and suspended at the end of 1929 , when the world depression began. It devalued in March 1930 (Butlin, 1986).

In Canada the first bank charters in 1821 required convertibility of bank notes into silver. A financial crisis and political instability in 1837 led to suspension. Resumption occurred in 1839. Canada adopted the gold standard in 1853 and, although it experienced a sharp cyclical downturn in 1907-08, it did not suspend convertibility until 1914 . However, no change was made in the statutory price of gold, and the gold reserve requirement for Dominion notes was not suspended, hence expansionary domestic monetary policy was subject to gold limits. Since export of gold was embargoed, exchange rates were at a discount from prewar parities. Canada restored legal convertibility at the prewar parity in July 1926 , making the monetary adjustments to return to parity without a central bank. The de facto date of Canada's suspension of gold convertibility was 1929 (Shearer and Clark, 1984, 300). Canadian banks could not ship gold abroad, but foreign holders of Canadian currency obligations could redeem them in gold. De jure suspension occurred in September 1931 when both internal and external gold convertibility ended.

Both Australia and Canada were as faithful as the core countries in adhering to the gold standard before 1914, but devalued in the post-World War I period. 


\subsubsection{Evaluating Peripheral Country Adherence to Specie Rules: Part 3, Segment A}

The record of the three Latin American countries, Argentina, Brazil, Chile does not match that of Australia and Canada.

Before it adopted the gold standard, from 1822 to 1825 Argentina had a brief spell of convertibility of bank notes. The metallic medium was silver and gold. Convertibility ended at a time of large government expenditures related to a war with Brazil. For the following 35 years, a period of continuing fiscal improvidence, there was no convertibility. Between 1862 and 1865 contractionary monetary policy was in force.

Gold convertibility in Argentina began in February 1867 after a failed attempt in 1863 (see also section 4 below). Convertibility was suspended in May 1876 after several years of political unrest and rising government deficits. Although the exchange rate reached parity by 1881 , resumption that year failed. Convertibility was restored in 1883 but lasted only until January 1885, at a time of financial crisis in Europe and following a period of expansionary fiscal policy. Again inconvertibility thereafter until 1899 was associated with lax fiscal policy leading to debt default in 1890 . In 1899 convertibility was restored with the return to fiscal orthodoxy in 1896 and the establishment of a form of currency board. Argentina suspended convertibility in 1914 on the outbreak of war. At a changed parity it resumed in August 1927 , and suspended again in 1929 . Inconvertibility prevailed during the balance of the interwar period.

From 1808 onwards Brazil followed a bimetallic standard at the colonial ratio of $16: 1$. From then until 1846 when it was altered to favor gold, the ratio was changed three times. Gold convertibility was suspended in November 1857 in the wake of a banking crisis, and resumed in 1858. It was susequently abandoned on several succeeding occasions (notably during the war with Paraguay). (Pelaez and Suzigan, 1976). It lasted for slightly more than a year in 1888-89. 1888 was the year slavery was abolished. In 1888-89 capital inflows were extraordinarily large. A republican revolution in November 1889 coincided 
with the ending of convertibility (Fritsch and Franco, 1992). The gold standard was identified with the deposed monarchy, and the new government introduced a system of regional banks to increase the money supply. The real exchange rate depreciated, and convertibility was suspended. As a condition for a large funding loan from London bankers, Brazil was required to shift to contractionary fiscal and monetary policies around the turn of the century.

In 1906 Brazil restored convertibility to prevent continued appreciation of the milreis exchange rate that was harmful to coffee and rubber exporters. In addition it created a Conversion Office with a limit set to its issue of convertible notes at a newly established parity. Brazil's external position deteriorated in 1913, owing to falling coffee and rubber prices and shrinking international capital flows following the Balkan wars. A cyclical decline lasted until the outbreak of World War I, when convertibility ended to preserve the gold holdings of the Conversion Office.

As was the case in 1906, resumption in 1926 was sought to prevent appreciation of the exchange rate. It followed a program in 1925-26 to achieve monetary and fiscal discipline. As in the earlier case, a Stabilization Office, modeled on the Conversion Office, was created to issue notes at the new parity. The collapse of coffee prices in 1929 and the contraction in capital inflows led in late 1930 to an almost complete loss of gold reserves by the Stabilization Office. Convertibility was then abandoned for the duration of the remaining interwar years.

Chile was on a bimetallic standard from 1818 to 1851 ; it then made a technical change in the mint ratio, continuing on the bimetallic standard until 1866, when it suspended. It resumed in 1870, but by the end of 1874 with the fall in the price of silver, it was on a de facto silver standard. Bad crops during the next three years, and accompanying balance of payments deficits, were followed by bank runs in 1878. The authorities made bank notes inconvertible on July 23, 1878 (Llona-Rodriguez, 1993).

For the next 17 years, Chile remained on a paper standard.In 1879 the War of the Pacific began, with Chile opposing Bolivia and Peru, and ended in 1883 with Chile the victor. The war was financed 
by government note issues. Thanks to its seizure of provinces in the losing countries, Chile became the world's monopoly producer of nitrate. However, declining prices of nitrate and copper in world markets led to depreciation of the Chilean peso from 1883 to 1893 , with the domestic inflation rate lower than exchange rate depreciation.

The first attempt to return to a metallic standard was made in 1887, but it failed. To appreciate the exchange rate, the government was required to retire its peso note issues and burn them, until the total issue had been reduced from 25 to 18 million pesos. It was also required to establish a silver fund for the eventual redemption of the outstanding amount. Bank issues were to be reduced from 150 percent to 100 percent of net worth, but neither margin was a real restraint. Bank notes rose and so did government notes.

An 8-month Civil War from January to August 1891 resulted in further monetary expansion and exchange rate depreciation. A second conversion law in November 1892 was strictly implemented and the exchange rate appreciated, but again the government responded to political discontent by issuing notes. The exchange rate thereupon depreciated. A new conversion law of February 11, 1895, set June 1 as the day for redemption of government notes, devalued the gold content of the peso, and authorized loans and sales of nitrate fields to accumulate a gold reserve. Bank notes, with limits on the authorized total, had to be backed by gold or bonds to be acceptable for taxes. As a result, the banks contracted and the money supply shrank.

Following rumors of war with Argentina and a run on the banks in July 1898, the legislature ended convertibility and, to deal with the panic, bank notes were declared government obligations. Chile did not resume until 1925, when it again devalued, and in 1931 it abandoned the gold standard.

Common elements in the experiences of the Latin American $\mathrm{ABC}$ countries that made their adherence to the gold standard chancy were war and threats of war and fiscal and monetary policies incompatible with fixed exchange rates. 
It is difficult, however, to isolate policy from balance of payments problems that were their lot as exporters of primary products whose prices were set in world markets. Whereas for core countries war was a contingency that justified abandonment of the standard, it was a temporary abandonment with the commitment to return to it; for the Latin American peripheral countries, not only the aftermath of war but deflation generally were reasons for absence of commitment to convertibility.

\subsubsection{Evaluating Peripheral Country Adherence to Specie Rules, Part 4, Segment A}

Except for Greece and Portugal, the record of adherence to specie rules is mainly blank for Italy and Spain, the Southern European countries included in Table 1.

For 42 out of the 52 years between 1833 and 1885 when it adopted the gold standard, Greece was en a bimetallic standard. Until 1828 it had no national currency; Turkish coins were the medium of exchange. A commercial bank, established in 1842, operated de facto as a central bank (Lazaretou, 1994).

Convertibility prevailed from February 1833 to March 1848, when suspension was declared for the balance of the year in response to panic worldwide. Resumption in January 1849 lasted through December 1868. Although Greece signed on as a member of the Latin Monetary Union in April 1867, it did not formally participate until November 1882 , when it defined 1 drachma as equivalent to 1 French franc.

Greece suspended for a year and a half until July 1870 because of revolution in Crete, which remained under Turkish occupation until 1899. It resumed in August 1870 until May 1877, which marked the end of its bimetallic experience. From June 1877 through December 1884, suspension was associated with the Russian-Turkish War of 1877-78. After the war ended, Greece made several attempts to resume, cutting back on monetary growth, while the government increased indirect taxes to raise revenues. From 1879 to 1884 it borrowed 360 million gold French francs. In 1882, it devalued the drachma. 
Despite gold outflows because of high interest payments and a trade crisis at the end of 1884 , Greece adopted the gold standard at that time. Convertibility, however, failed as gold outflows persisted, and by September 1885 Greece reverted to a paper money standard and floating exchange rates.

Continued borrowing from France until 1891 and low tax revenues led to debt default in December 1893.

The defeat of Greece in 1897 in the war with Turkey, which saddled it with a huge war indemnity payable in funds convertible into gold, was the spur for the appointment in 1898 of an International Committee for Greek debt management. The Committee imposed fiscal prudence on the government, and a loan of 150 million gold French francs was arranged to enable Greece to pay the war indemnity to Turkey.

These measures restored confidence in Greek monetary and fiscal policies. A law of March 1910 required note circulation above a statutory ceiling to be backed by gold or foreign exchange. Bank notes were to be convertible into French francs at parity, and official reserves of the National Bank of Greece were stipulated as mainly interest-bearing deposits denominated in foreign currencies. In April 1910 Greece resumed convertibility on the gold exchange standard.

The new standard was successful until December 1914. Money creation then financed wartime spending. Exchange rate parity was maintained until reserves were depleted by August 1919. Exchange rates floated until May 1928, when Greece returned to the gold exchange standard. It instituted foreign exchange controls in September 1931 and devalued in April 1932, when convertibility ended.

Italy, unlike Greece, adhered to a specie standard only for 14 years during the 52 years before World War I but operated a paper standard during most of the rest of the period as if subject to specie constraints. In 1862 it adopted the bimetallic standard, although de facto the standard was gold. In 1865 Italy joined the Latin Monetary Union. Fiscal improvidence and war against Austria in 1866, however, ended convertibility (Fratianni and Spinelli, 1984). 
Fiscal and monetary discipline was achieved by 1874 , and exchange rate parity was restored. The government announced on March 1, 1883, that it would restore convertibility on April 12, 1884, but convertibility took place only in silver because silver was overvalued at the mint. Public finances then deteriorated and unlawful bank issues indicated an absence of monetary discipline. By 1894 Italy was back on a paper standard, and floating exchange rates. Inconvertibility lasted until 1913. After periods of laxity, the government embraced fiscal and monetary rectitude as if it were on a gold standard.

Italy did not return to the gold standard until December 1927. It resorted to foreign exchange controls in May 1934, and devalued in October 1936.

Portugal was nunner-up to Greece in the number of years it adhered to specie rules (Reis, 1992). It had been on a bimetallic standard since the 1680 s with de facto gold predominance alternating with de facto silver predominance. In 1846 it was a weak country facing a civil war, and in no position to mint its own coin to any great extent. Instead, Portugal legalized silver coinage from other countries and set a new gold parity for the milreis at 4.5 to the pound sterling that effectively ensured that English money would mainly be the foreign inflow. England was Portugal's chief trading partner and creditor, to whom it shipped English coin to settle its accounts. Furthermore, the mint ratio the law established favored gold.

The decision to shift to a gold standard in 1854 was made by the government as the most convenient for Portugal since gold circulation was ample, and Bank of Lisbon paper that had been circulating at a discount was virtually back to par. The parity with the pound was unchanged from 1854 until 1891, during which there were no convertibility crises. Gold coins circulated, notes and deposits constituting a minor proportion of the money supply. Yet Portugal's balance of trade, except for one year, was in deficit, and it was a net capital importer. Moreover, the government budget was typically short of revenue, but until 1890 Portugal succeeded in borrowing long-term funds at home or abroad to cover the shortfall. 
In addition to borrowings, Portugal offset the negative elements in its balance of payments by remittances from Brazil and by earnings on Portuguese foreign investments. Thus Portugal, a debtor nation, was a regular importer of gold, unlike other peripheral nations. All this came to a halt in 1891 , after which it was no longer able to raise foreign loans. An increase in the ratio of its debt service payments to revenues, and government support of failing Portuguese enterprises clouded its reputation as a creditworthy nation. The finance minister in office at this juncture was a soft-money silver supporter, which did not help Portugal's credit standing. Portugal's suspension of convertibility in 1891 lasted until after World War I.

It returned to gold in July 1931 at a devalued parity and suspended two months later with England.

Although Spain adopted a bimetallic regime in April 1848, it was not until the currency reform of 1868 that established the peseta as the monetary unit that the regime was fully operative (Martin Acena, 1993). In 1868 the gold-silver ratio was set at 15.5:1, as in the Latin Monetary Union (which Spain did not join), whereas the 16:1 ratio set in 1848 was followed by six reductions in the intervening years. The Bank of Spain in 1874 became the monopoly issuer of bank notes that were freely convertible into both gold and silver.

With the fall in the market price of silver in the 1870s, the 15.5:1 ratio undervalued gold. Gold was driven out of circulation, and the gold reserves of the Bank of Spain declined, but until mid-1883 trade surpluses and capital imports sustained convertibility. Because foreign holders of Spanish bonds refused to accept the terms of a conversion the Treasury was engaged in at the time, there was a capital outflow and a fall in inflows. In addition, the trade balance declined sharply from 1881 to 1883 . To avoid deflation, Spain ended convertibility.

Between 1888 and 1900 the peseta exchange rate depreciated, a budget deficit arose in every year but three from 1884 to 1899 , the war with Cuba in 1898-99 was financed largely by money creation, and 
Spanish prices until 1905 fell much less than world prices - all factors hostile to resumption. These factors mainly after 1900 turned favorable to resumption, but it did not take place. Efforts by finance ministers to restore convertibility and adopt the gold standard before World War I foundered on the opposition of the Bank of Spain. Unlike other countries, Spain did not even briefly during the interwar period turn to gold convertibility. It adopted foreign exchange controls in May 1931.

\subsubsection{Evaluating Peripheral Country Adherence to Specie Rules, Part 5. Segment A}

The Scandinavian countries were as faithful adherents to the classical gold standard as were the core countries. Sweden and Denmark were independent countries throughout the period. Only Sweden of the group has a monetary history available to us for the early nineteenth century, and its record of respect for specie rules during that period is not inferior to that of the core.

Sweden had a silver standard from 1803 to 1809 . Large budget deficits to finance a war with Russia in 1808 bloated the money supply. In 1809 convertibility was suspended. A silver standard was not restored until 1834. It lasted until 1873 when Sweden adopted gold. The four Scandinavian countries show a common pattern of adoption of the gold standard between 1872 and 1877 and adherence to the standard until 1914.

Even during the period when the four countries adopted the gold standard, Finland and Norway were not independent. The former was an autonomous grand duchy of the Russian empire until 1917, the latter part of Sweden until 1905.

The Swedish constitution guaranteed the convertibility of the central bank's notes into gold, as noted in Section 2.1 above. For a change in gold standard arrangements to be adopted Parliament had to give its assent at two different dates with an election intervening. The central bank's decision in 1914 to make the notes inconvertible was unconstitutional since the bank disregarded the provision for Parliamentary approval. 
Only Finland devalued on resumption in 1926. The others resumed at their prewar parities. Sweden returned to gold de jure in March 1924, but de facto the prewar par rate of the krona in gold was restored in 1922. What delayed the de jure return was the authorities' opposition to the krona as the sole convertible European currency. All the Scandinavian countries suspended in 1931 and devalued. In June 1933 the Swedish krona was fixed to the British pound, and the exchange rate was unchanged until after the start of World War II.

\subsubsection{Evaluating Peripheral Country Adherence to Specie Rules, Part 5, Segment A}

The three Western European countries, Belgium, the Netherlands, and Switzerland, adopted the gold standard in the second half of the 1870s and adhered to it until World War 1 .

A note-issuing bank was established in Belgium in 1822 before it became independent in 1832, when it was a bimetallic adherent. It suspended convertibility in 1848 in the face of French political and financial problems. The Netherlands was on a bimetallic standard in 1847, Switzerland in 1850.

All three countries suspended convertibility in 1914. Belgium lost the right of note issue when the Germans took over. Switzerland declared bank notes legal tender in 1914. The Netherlands prohibited gold export in 1914. Belgium devalued when it returned to gold in October 1926, and devalued again in March 1935. The Netherlands returned to gold at the prewar parity in April 1925 and devalued in October 1936. Switzerland did not devalue in 1929 when it returned to gold but when it left the gold standard in 1936 it did.

\subsubsection{Evaluating Japan's Adherence to Specie Rules, Part 5. Segment A}

Convertibility was not firmly established in Japan until 1885 , when it was on a silver standard (Shinjo, 1962).

In 1868 Japan introduced a new monetary unit, the yen, defined as the same weight and fineness as the Mexican silver dollar. In an act of 1871 Japan prescribed a gold yen, but silver still remained the preferred metal for foreign trade. Bimetallism was in effect as judged by the government's metallic 
reserve. The government issued notes beginning in 1868 that were redeemable in silver, with an 1880 expiration date of redemption. In addition, government-issued currency notes were inconvertible. ${ }^{12}$

New national banks were created late in 1872 to issue bank notes against specie reserves of not less than two-thirds the amount emitted. The notes, however, quickly returned to the banks for redemption in silver. The petition in 1875 of four existing national banks to change from silver to government currency note convertibility was granted the following year. National banks multiplied and their issues sharply increased. ${ }^{13}$

From 1868 until 1878 the paper currency depreciated against both silver and gold. The government issue ceased in 1879. It was recognized that a budget surplus was essential to decrease the outstanding note issue and to accumulate specie. By 1881 , after keeping government expenditure constant for three years, the government budget was in surplus, used partly to destroy existing notes and the rest as specie reserve.

In October 1882 the Bank of Japan was founded, but it did not issue convertible notes, payable in silver on demand, until 1885 . These notes, initially limited in amount, replaced government currency notes. In 1888 the bank was authorized to issue a substantial fiduciary circulation backed by government and commercial paper, any amounts in excess to be backed by gold and silver. National banks lost the right of issue after the expiration of their charters. Deposit banks replaced them.

The premium on silver disappeared once convertibility was established but, since the price of silver against gold was declining, the exchange rate against gold standard countries was unstable. By 1893 Japan recognized that it was desirable to adopt the gold standard, but the reform was not introduced until the indemnity in gold China paid for losing the Sino-Japanese war of 1894-95 enabled the government to acquire an adequate reserve. 
The Coinage Act of 1897 established the gold standard. The act governing the Bank of Japan was revised to require convertibility of its notes into gold instead of silver. The government contribured the gold indemnity to the bank's reserve. Silver was limited to one-fourth of the specie reserve.

Japan adhered to the gold standard until September 1917, without interruption despite runs on banks in 1901 and 1907-08, war with Russia in 1904-05, extraordinary government expenditures financed by foreign loans, an unfavorable balance of payments during most of the period. The decrease in the specie reserve prompted flotation of foreign bonds in London and Paris in every year from 1906 to 1915. Foreign capital maintained Japan's gold standard.

Japan was a beneficiary of the demand for its goods and services by World War I belligerents. It used the surplus in its balance of payments to increase the Bank of Japan's and the government's gold reserves, to replenish its foreign exchange balances abroad, to pay back foreign loans, and to increase its foreign investments. Japan became a creditor country.

In September 1917 Japan followed the United States in embargoing gold and silver expor. Bank of Japan notes became inconvertible. Wartime prosperity ended in 1920, with failures of firms and runs on banks. A deflationary policy in 1921-22 provoked further runs on banks, and the policy was discontinued. An earthquake in September 1923 led to increased government expenditures. Again there was a move to deflation and a readiness to follow England's return to gold in April 1925. Financial panic in 1926 halted that step. A new government in 1929 adopted a program of lifting the gold embargo and returning to gold at the prewar parity, as it did in January 1930.

Speculative transactions to sell yen and buy dollars once the gold standard was restored reflected the market's belief that the yen would have to be devalued. The suspension of the gold standard in December 1931 came after huge gold losses by Japan. In March 1932 Japan began a series of devaluations of the gold content of the yen as the exchange rate of the yen declined. Foreign exchange 
controls were introduced in May 1933. The limit on the Bank of Japan's fiduciary note issue was repeatedly expanded, and ultimately eliminated.

\subsection{Evaluating Core Country Adherence to Rules: Segment B}

Under Bretton Woods, the rule for countries other than the United States was that a change in par value was permissible to correct fundamental disequilibrium. Though undefined, the term was intended to refer to disturbances other than government policies that justified a change in par. Examples of such disturbances were a change in the terms of trade and in productivity trends, and other contingencies similar to those the gold standard escape clauses encompassed. Obtaining the advance agreement of the IMF to a change in par was a way of insuring that such were the disturbances that prompted the action (Eichengreen, 1994).

As is well known, the Bretton Woods arrangements required countries other than the United States to peg their currencies to the dollar, and the United States to peg the dollar to gold. The system became fully operative in 1959 and broke down in 1971 . The rules for neither the center nor the other countries were successful (Bordo, 1993a; Giovanini, 1993).

Problems raised by the rule for countries other than the United States were apparent from the start of the system. We review the problems as evidenced by core country performance. When France devalued in January 1948, it did not seek IMF authorization. By creating multiple exchange rates, it took a discretionary action, contrary to the rule. It then restored unified exchange rates in the devaluation of 1949. The U.K. announced convertibility for current account transactions in July 1947, but suspended the next month, making sterling subject to exchange controls. It declared a par value in 1948, but devalued in September 1949 by a larger percent than it had indicated to the IMF.

After the general realignment of September 1949, in which Germany joined, changes in par of the core countries were rare, possibly due to reluctance to alter their parities after the experience of the speculative attacks that occurred after the 1949 changes. Keynesian full-employment policies that many 
countries adopted conflicted with Bretton Woods obligations to maintain fixed exchange rates. In consequence, exchange rate crises erupted as market participants anticipated policy-induced pressures to devalue or revalue. The countries whose currencies the market targeted for attack resisted changing par values in the belief that domestic concerns should not yield to external concerns. They tried to buy time by imposing capital controls and deploying international reserves to preserve existing par values, but in the end failed. The meaning of fundamental disequilibrium, however, was altered to refer to government monetary and fiscal policies that were inconsistent with those par values. As events unfolded, it was difficult to distinguish the original correct use from this incorrect use of the escape clause.

The core country par values that changed reflected this shift in the meaning of fundamental disequilibrium. Two examples are France, under inflationary conditions, which devalued in 1957 and 1958, and the U.K.. Chronic U.K. balance of payments deficits during the 1960 s led to devaluation of sterling in November 1967, despite rescue packages. France suspended the par value of the franc in November 1968 because of speculative attacks on its currency in conditions of social unrest and inflation. Capital controls and massive international loans were not effective in preventing devaluation in August 1969. In contrast, Germany in response to a persistent balance of payments surplus reflecting higher productivity than her partners revalued in 1961. In 1968 it resorted to border taxes and restricted capital inflows, but ultimately revalued in September 1969.

During 1969-71 a persistent outflow of funds from the United States overwhelmed foreign exchange markets. In May 1971 Germany suspended dealings in D-marks and allowed its currency to float, since it could not maintain exchange rates within the established margins. France introduced dual exchange rates in August 1971, and the U.K. suspended the sterling par value that month, and allowed sterling to float in June 1972.

If countries other than the United States did not observe the Bretton Woods rule on par value change as it was conceived, neither did the United States, the center country, comply with the gold 
convertibility rule. Faced with balance of payments deficits after 1957 that increased dollar liabilities while the monetary gold stock was shrinking, the problem for the United States was how to preserve convertibility. Many stratagems were devised to induce holders of dollars to refrain from cashing them in for gold. In addition, the elimination of the gold reserve requirement against Federal Reserve notes in 1968 betokened a weakening of the commitment mechanism to maintain stable money - an obligation of the reserve country. Moreover, by engaging in expansionary monetary policy after the mid-1960s, the United States exacerbated the convertibility problem since the incentive to hold dollars declined as inflation rose. The closing of the gold window in August 1971 marked the end of the convertibility rule and the readjustment of currency parities at the Smithsonian meeting in December 1971 marked the first dollar devaluation since 1934 .

\subsection{Evaluating Peripheral Country Adherence to Rules, Segment B}

Like the core countries, peripheral countries under the Bretton Woods system differed in the extent to which they adopted expansionary monetary and fiscal policies. High inflation countries repeatedly devalued; low inflation countries did not.

Australia, at the start of the Bretton Woods era, was part of the sterling area. Along with the U.K. it declared the par value of its pound in 1947 and devalued in 1949. In 1966 it changed its currency unit to the Australian dollar, as it converted its currency to the decimal system. No appreciation or depreciation of the exchange rate accompanied the new monetary unit. Australia did not devalue with the U.K. in 1967. It suspended its par value in August 1971, but did not change it, so its currency appreciated relative to the U.S. dollar from the par value that existed before the closing of the U.S. gold window.

Canada declared its par value at the end of 1946 and devalued with the U.K. in 1949. It acquired a special status under Bretton Woods when the IMF did not actively oppose its decision to float its dollar in September 1950. Capital inflows from the United States were increasing Canada's reserves, with 
expansionary consequences for its money supply. Under fixed exchange rates Canada found it difficult to resist the inflationary results. It did not revert to fixed exchange rates until May 1962. In May 1970 Canada again decided to float for the same reason as it did two decades earlier. Its foreign exchange reserves were accelerating, and the situation that was created thereby was deemed unmanageable under fixed rates. Canada continued to float until the collapse of Bretton Woods.

The Latin American countries all had high inflation experiences during the Bretton Woods era. Before Argentina declared its par value in 1957 it had in 1955 introduced multiple exchange rates. It devalued in 1959,1962, and 1970. Brazil was plagued by inflation from World War II on and especially after 1958. It devalued in 1967, and in August 1968 introduced a flexible exchange rate policy which involved devaluation of the currency by small amounts at frequent irregular intervals. Similarly, Chile, which declared its par value in 1946, introduced multiple exchange rates in 1953 and devalued in 1962.

Of the four Southern European countries, only Spain devalued before 1971. It did so in November 1967 . The IMF regarded the devaluation as a correction of a previously existing fundamental disequilibrium. In 1971 Spain maintained its par value unchanged but widened the margin to up to 2 $1 / 4 \%$.

Only Sweden of the Scandinavian countries did not devalue between 1951, the date of par declaration, and 1971. Denmark devalued in 1949 and 1967. Finland devalued in 1957 and 1967. Norway devalued in 1949.

In Western Europe Belgium and the Netherlands realigned with Germany in 1949 and the latter revalued with Germany in 1961.

Japan did not devalue between 1949, when it declared its par value, and 1971.

\subsection{Conclusion}

The chronology of adherence to rules before and after Bretton Woods reveals a decay of respect for rules over the century Table 1 covers. Rules were not universally honored even during the classical 
gold standard era. A core group of countries was usually faithful to specie rules, but countries in Western Europe, the new Anglo settlement countries, and the Scandinavian countries also conducted their financial affairs so that the fixed price of gold that defined their currencies was unchanged for extended periods. Monetary and fiscal policies in the remaining countries in the table were such that suspensions of the specie rule were not exceptional, and they were followed by changes in the former parity. Only extraordinary events like wars occasioned departures from the standard among the core and their cohorts and until World War I resumption took place at the prewar parity.

In the interwar period a return to the gold standard was sometimes at the earlier parity, but often at a devalued rate. During most of the period floating exchange rates were common. The attempt under Bretton Woods to impose a rule that the par value of its currency with the dollar that each country member declared would be changed only under extraordinary circumstances as under the classical gold standard failed. Domestic economic objectives proved to be paramount to international obligations.

\section{Capital Flows and Specie Standard Adherence:}

Argentina and the United States, 1865-1914

One of the enforcement mechanisms of the specie standard rule for peripheral countries was presumably access to the capital needed for their economic development from the core countries. Adherence to the convertibility rule would be viewed by lenders as evidence of financial probity - i.e. membership in the international gold standard would be like 'the good housekeeping' seal of approval. It would signal that a country followed prudent fiscal and monetary policies and would only temporarily sun large fiscal deficits in well understood emergencies. Moreover, the monetary authorities would be willing to go to considerable lengths to avoid defaulting on externally held debt. It would also presumably be a signal to the lenders in London and other metropolitan areas that the groups in power observed similar standards of financial rectitude. 
This suggests that adherence to the specie standard rule, ceteris paribus, would make a difference in the volume of capital a country attracted from abroad. Presumably loans would only be made with gold clauses (or be sterling denominated) so that currency risk would not matter. But there still would be a risk of abrogation of the gold clauses or of total default on the debt. That eventuality would be reflected in a risk premium on the loan. In that case it would be attractive to a potential borrower to adhere to the specie standard rule as a signal of financial responsibility to induce the lender to lower the risk premium. ${ }^{\text {is }}$ But a more fundamental problem could arise in a world of asymmetric information with the possibility of a 'lemons premium' (Akerlof, 1970; Stiglitz and Weiss, 1981). In that case, charging a high interest rate might attract borrowers willing to engage in unduly risky projects. Lenders faced with imperfect information on the borrowers' likely actions would then be reluctant to lend at any price. A credible commitment to the specie standard rule, as evidenced by the holding of substantial gold reserves, would provide a signal to lenders of the costs borrowers would be willing to bear to avoid default, and hence would circumvent the aversion to lending imposed by asymmetric information.

As a tentative step in the direction of examining the connection between capital flows and adherence to the specie standard rule, we briefly focus on the experience of two major borrowers of British capital in the late nineteenth century, each of which had a record of suspension and of specie standard adherence over the period 1865-1914 - Argentina and the United States. In that fifty year period, Argentina was off gold in three episodes of suspension totalling twenty four years (excluding the general breakdown of the international gold standard in 1914). The U.S. was off gold for seventeen years and the gold standard subsequently was under threat of suspension for another seven years.

In figures 1 and 2 we present annual data on capital calls on new issues of securities - a measure of access to new capital in London for the two countries. The data, kindly supplied by Lance Davis, underlying Davis and Huttenback's (1986) study of the economics of British imperialism ${ }^{15}$, are expressed 
in millions of current U.S. dollars. ${ }^{16}$ The periods of suspension (and for the U.S. the episode of silver threat to the gold standard) are marked off in the figures by shaded areas.

An ideal analysis of the influence of adherence to the specie standard rule would be based on a model of the determinants of capital flows, including such variables as: the expected real rates of return in both countries, the levels of real activity, the terms of trade, and the phase of the business cycle (see Ford, 1962; Abramowitz, 1973; Edelstein, 1982). One could then test for the marginal influence of adherence/non adherence to the rule. Here our aims are much more modest - to simply compare the annual capital calls on new issues of securities with a chronology of events related to adherence to the rule. Any connection revealed should be treated merely as highly suggestive.

Bertalomé Mitre became president of Argentina in 1862 and succeeded in unifying the country after five decades of intermittent civil strife, external wars and highly unstable monetary and fiscal policies (Contes-Condé, 1989). Under Mitre, contractionary monetary and fiscal policies were successful in achieving specie convertibility in 1867 (following a failed attempt in 1863). Argentina then began five decades of extraordinary economic growth with rapid development in agriculture, transportation, and commerce. It also was the start of a wave of immigration from Europe and of the massive inflow of capital (Cortes-Condé, 1986). The pattern for Argentina in Figure 1 reveals little change in capital flows from a low and stable level when the country joined the gold standard in 1867 until 1876 . The period 1870-75 is characterized by a mild boom in capital calls, ending just before suspension of convertibility in 1876 . It would be difficult to disentangle the effect of establishing convertibility in 1867 from that of restoring political stability as the key determinants of the beginning of capital flows from Europe.

Increasing civil strife in 1873-76, rising government deficits, and a downturn in the world business cycle account for the suspension of convertibility in 1876. It was followed by several years of negligible capital inflows. Thanks to contractionary fiscal policy in the late 1870 's, the exchange rate reached parity in 1881 but it took until 1883 to restore convertibility (Cortes-Condé, 1989). The 
commitment to restore convertibility may have led to the observed resumption of capital inflows. Convertibility was shortlived, however. Expansionary fiscal policy in 1884 led to a crisis and suspension on January 1,1885 . Again suspension is associated with a decline in capital flows but the significant rebound from 1886 to 1889 under inconvertible money suggests that British investors placed more weight on the long-run economic prosperity of the Argentine economy than currency stability. The boom ended with a crash in 1890 , following several years of exceedingly loose fiscal policy and the creation in 1887 of a free banking system which produced a plethora of bank money (Eichengreen 1992b). A revolution in that year, followed by default on external debt, precipitated the Baring crisis in London. Capital inflows then plummeted until the authorities again instituted monetary and fiscal austerity. It took four years for convertibility to be restored in 1899 . Restoration of convertibility along with the creation of a quasi currency board (the Caja de Conversion), which in essence tied the hands of the monetary authorities, succeeded in creating a climate conducive to the resumption of significant capital movements until World War I.

This narrative suggests that adherence to the rule by Argentina may have had some marginal influence on capital calls on new issues of securities in London before 1890 (see Table 2 which suggests that the mean of capital calls in current and real dollars was higher during periods of adherence than of suspension), but that the key determinant was the opening up of the country's vast resources to economic development once unification and a modicum of political stability were achieved. The 1890 crisis was a major shock to investor confidence and it took years of austerity, the restoration of convertibility, and the establishment of a currency board before British investors' confidence was restored.

The U.S. experience under suspension has been well studied by others (Sharkey, 1959; Unger, 1964; Friedman and Schwartz, 1963; Roll, 1972; Calomiris, 1988). As can be seen in Figure 2 capital calls on new issues were low in the first five years after the Civil War. The debate over resumption in these years seems to have had little impact on the decision by investors to purchase securities in London 
destined for the United States, but then purchases picked up significantly in 1870 and 1871 . This phenomenon may be explained by the Public Credit Act of 1869 which guaranteed that the principal on U.S. government bonds would be payable in gold (Calomiris, 1988). The subsequent decline may reflect adverse news of the likelihood of resumption with the reversal in 1871 of an earlier Supreme Court decision declaring the issue of greenbacks unconstitutional, as well as the Treasury's expansionary fiscal policy (Calomiris, 1993). Capital calls increase until they are reversed by the Panic of 1873, a decline in economic activity, and two years of soft money victories (the reissue of retired greenbacks in 1873 and the Inflation Bill of 1874). The Resumption Act of 1875 is then followed in the next two years by the largest increase in capital inflows over the whole fifty-year span. Resumption of specie payments on January 1,1879 , is followed by a rising but variable trend in capital calls on new issues but the volume is well below the average of the suspension period (see Table 2).

The period 1890-96 is important in the history of U.S. adherence to the rule. Passage of the Sherman Silver Purchase Act in 1890 led to a six-year period of uncertainty surrounding the nation's ability to remain on the gold standard (Friedman and Schwartz, 1963; Calomiris, 1993; Grilli, 1990). This episode is reflected in the capital calls on new issue series in figure 2. They peak in 1890 and though they may have rallied following the repeal of the silver purchase part of the Sherman Silver Act in 1893, and the Belmont Morgan syndicate replenishment of the Treasury's gold reserves in 1895, they rebound significantly only after the 1900 Gold Standard Act.

In sum, for the U.S. as for Argentina, events suggesting the restoration of convertibility during suspension and threats to convertibility during adherence seem to be associated with increases and declines in capital calls on new issues of securities in London. More systematic research is required to cistinguish these influences from the fundamental determinants of capital flows. 


\section{The Economic Performance of Core and Peripheral Countries under Alternative}

\section{Monetary Regimes}

In this section of the paper we present some evidence based on annual data over the past one hundred and ten years on the macroeconomic performance of the four core countries and seventeen peripheral countries during the classical gold standard (1880-1914) and three successive monetary regimes: the Interwar period (1919-1939); the Bretton Woods international monetary system (1946-1970); and the recent managed float (1974-1990). The Bretton Woods system, as a variant of the contingent specie standard rule, is directly comparable to the classical gold standard. The recent managed float, a regime not based on the rule, and the interwar period, which comprises episodes of free floating, adherence to the gold standard, and managed floating, are presented as contrasts to the two rule-based regimes. ${ }^{17}$ The data are organized in the seven groupings shown in Table 1 , as well as broader aggregates.

Such evidence for the classical gold standard regime and for Bretton Woods may shed light on whether differing economic performance can explain why some countries successfully adhered to the convertibility rule and others did not, or whether adherence/nonadherence to the rule may have influenced performance. By contrast, under the recent floating regime we seek to determine whether the observed differences between countries' performance under convertible regimes persist in the absence of rules.

\subsection{Stability and Convergence}

Tables 3 through 5 present descriptive statistics on three macro variables for each country pertinent to the issue of adherence to convertibility rules, the data for each variable converted to a continuous annual series from 1880 to 1989 . The three variables are: the rate of inflation (GNP deflators), money growth, and the ratio of Government expenditure less Government Revenues to GNP. ${ }^{18}$ The definition of the variable used, e.g., $M_{1}$ versus $M_{2}$, was dictated by the availability of data over the entire period. For each variable, and each country we present two summary statistics: the mean 
and standard deviation. For each of the seven country groupings from Table 1, and four aggregate groupings (all countries, all except the four core countries; the G-10 countries plus Switzerland [G-11]; and all except the G-11) we show as a summary statistic: the grand mean. We comment on the statistical results for each variable.

\subsubsection{Inflation (Table 3)}

The classical gold standard had the lowest rate of inflation of any monetary regime for all 21 countries and the interwar period displayed mild deflation for all except Latin America. Within the classical gold standard regime, the inflation rate was lowest in countries identified in Table 1 as following the convertibility rule: the four core countries; some of the different European groupings and the Anglo countries of new settlement. It was considerably higher in Latin America and Japan. This pattern can also be seen in a comparison of the G-10 plus Switzerland aggregate (an expanded core group) with the other peripheral countries. The former grouping contains nine countries which followed the rules; the latter only three.

Under Bretton Woods, like the gold standard, a distinct difference can be observed between the core countries and a number of other groupings (Anglo new settlement, other Western Europe, Japan), which had low inflation; and a set of countries with higher inflation (Latin America, to a lesser extent countries in Southern Europe and Scandinavia). This observed difference between country groupings also is found under the recent float. The evidence on inflation suggests that if the specie standard rule or its variant did provide a credible commitment mechanism for low inflation, it was strongest in the gold standard period followed by Bretton Woods. Within these regimes observance of the rule clearly demarcates inflation performance between countries.

The gold standard period had the most stable inflation rate of any regime (across all countries) judged by the standard deviation. This was followed by Bretton Woods, the interwar and then the float. For the G-11 countries, the recent float is the most stable period. Within the gold standard regime, core 
countries and countries following the specie standard rule exhibited greater price stability than the others. For Bretton Woods a similar difference between country groupings is observed, with Japan joining the stable inflation group, and Southern Europe the unstable inflation group. These differences persist into the recent float.

The evidence of a high degree of price stability under the gold standard (and to a lesser extent under Bretton Woods) and of greater price stability during those periods in countries following the rules compared to those that did not is consistent with the traditional view that commodity-money-based regimes provide a stable nominal anchor; however, the price stability observed may also reflect the absence of major shocks.

\subsubsection{Money Growth $\left(\mathrm{M}_{2}\right)$ Table 4.}

It was considerably more rapid across all countries post-World War II than before the war. For the core countries and most of the G-11 countries there is not much difference between Bretton Woods and the subsequent floating regime. Southern Europe, Latin America and Japan exhibited considerably higher money growth under Brerton Woods than the others. For the Latin American countries money growth rates accelerated over the entire postwar period reaching their highest levels under the float. By contrast with the postwar, the gold standard exhibited lower money growth in both core and peripheral countries alike with the principal exception of Japan; however, it was still higher in core than peripheral countries. The observance of lower money growth in both core and peripheral countries may be a reflection of the omnipresence of the specie standard rule.

Across all countries, money growth was least variable in the interwar and most variable in the tecent float. However, for the core and G-11 countries it was least variable under the gold standard. Under that regime money growth variability was higher in the periphery than the core. Under Bretton Woods and the recent float the difference between core and periphery money growth variability is less obvious, again with the principal exception of Latin America which exhibits considerably greater money 
growth variability than all other countries. For these countries the increase in money growth variability reflects the breakdown of any linkage to a commitment regime.

\subsubsection{Government Deficit (Table 5).}

For all 21 countries the average ratio of the government deficit to GNP is lowest during the Bretton Woods period, followed by the gold standard. The highest ratio is for the recent float. In all regimes, average deficit ratios are higher in peripheral than core countries. (This also holds comparing the G-11 with the rest). Under the gold standard, the highest average ratios were in the Anglo countries of new settlement and Latin America; under Bretton Woods they occurred in Latin America and under the float in Latin America and Southern Europe. The standard deviations in fiscal policy followed a pattern similar to the means -- they are generally lower in core than peripheral countries. Thus, adherence to convertibility rules may have constrained fiscal policy in the same way as it did monetary policy. On the other hand, more limited fiscal needs during these regimes may have made it easier to adhere to the convertibility rule.

One group of countries stands out in the cross-country comparison. For the Latin American countries the fiscal deficit as a share of GNP increases dramatically between the pre-World War II and post-World War II regimes. In the postwar period it increases between regimes, reaching a peak with the float. Indeed a closer correlation between the fiscal deficit, money growth and inflation can be observed across regimes for these countries than is the case for most countries in the G-11. Such a correlation may be evidence of lack of credibility in the commitment of the monetary regime.

\subsubsection{Summary}

In summary, the gold standard regime had the lowest and least variable inflation performance for all countries. However, within that regime peripheral countries performed worse than the core (and expanded core). Bretton Woods exhibited a similar pattern with somewhat higher overall inflation. By contrast the recent float displayed both higher and more variable inflation than both regimes. This 
evidence may reflect a favorable influence of regime adherence on performance, but on the other hand adherence may have been possible because of greater stability.

Money growth was generally lowest and most stable under the gold standard across all countries, followed by Bretton Woods. Core countries within each regime followed more prudent and stable monetary policies than the periphery. By contrast, under the float, money growth was considerably higher, less stable across all countries. Lower and more stable money growth by core countries under the gold standard compared to the periphery may reflect better adherence to the commitment mechanism or alternatively that there was less pressure to gear monetary policy for domestic purposes (Eichengreen, 1992b). The fact that peripheral countries' money growth was still relatively low and stable compared to later regimes may reflect their intention to adhere to the rule, when conditions were favorable. A similar but more muted pattern is observed in comparing Bretton Woods to the subsequent float.

Finally, the fiscal deficit, like monetary policy, is lowest and most stable under the gold standard, followed by Bretton Woods and in sharp contrast to the recent float. Within these regimes however, weaker performance is observed for peripheral countries. Again like monetary policy, intended adherence to the regime, ceteris paribus, may have restrained policymakers during these periods compared to the recent float.

Thus, this statistical evidence reveals substantial differences in economic performance across regimes as well as differences between countries' and groupings of countries' performances within regimes. It is not clear however how much the different performance reflects adherence or non adherence to rules and vice versa. Analysis of the shocks facing different countries may shed more light on this issue.

\subsection{Demand and Supply Disturbances}

An important issue is the extent to which the performance of alternative monetary regimes, as revealed by the data in the preceding tables, reflects the operation of the monetary regime in constraining 
policy actions or the presence or absence of shocks to the underlying environment. One way to shed light on this issue, following earlier work by Bayoumi and Eichengreen (1992a) (1992b) (1993) (1994), is to identify underlying shocks to aggregate supply and demand. According to them, aggregate supply shocks reflect shocks to the environment and are independent of the regime, but aggregate demand shocks likely reflect policy actions and are specific to the regime.

The approach used to calculate aggregate supply and demand shocks is an extension of the bivariate structural vector autoregression (VAR) methodology developed by Blanchard and Quah (1989). Following Bayoumi and Eichengreen (1992a), we estimated a two-variable VAR in the rate of change of the price level and output. ${ }^{19}$ Restrictions on the VAR identify an aggregate demand disturbance, which is assumed to have only a temporary impact on output and a permanent impact on the price level, and an aggregate supply disturbance, which is assumed to have a permanent impact on both prices and output. ${ }^{30}$ Overidentifying restrictions, namely, that demand shocks are positively correlated and supply shocks are negatively correlated with prices, can be tested by examining the impulse response functions to the shocks.

The methodology has important limitations which suggest that the results should be viewed with caution. The key limitation is that one can easily imagine frameworks in which demand shocks have permanent effects on output while supply shocks have only temporary effects. ${ }^{21}$

We estimated supply (permanent) and demand (temporary) shocks, using annual data for each of the 21 countries, over alternative regimes in the period 1880-1989. The VAR's are based on data for three separate regime periods (to the extent available): 1880-1913, 1919-1939, and 1946-1989, omitting the war years because complete data on them were only available for a few of the countries. The VAR's have two lags. We also did the estimation for aggregated price and output data for the seven country groupings and for the four broader aggregates of countries. 
Table 6 presents the standard deviations of supply and demand shocks for the 21 countries by regimes. We also present aggregate shocks for the seven country groupings and for the four broad aggregates of countries. In addition we show, following Bayoumi and Eichengreen (1992a), the weighted average of the individual country shocks.

Table 6 shows for the seven country groupings, with the principal exception of Latin America, that the recent float regime was the most tranquil, with the lowest demand and supply shocks. The interwar period, again with the exception of Latin America, was the most volatile. ${ }^{22}$ Bretton Woods experienced relatively high demand shocks in most of the country groupings with the exception of Japan. This likely reflects the widespread use of Keynesian demand management policies in this period. By contrast supply shocks were quite low across all groupings, not much different from the float. The gold standard in general exhibited fairly sizeable supply shocks. Indeed, for the core countries, the Anglo Saxon countries and Japan they were more than twice as high as in the post-World War II period. ${ }^{23}$ In Latin America demand shocks exceeded supply shocks in all regimes except the interwar. In the postWorld War II period, for these countries, demand shocks considerably exceeded supply shocks, especially under the float. For these countries the constraints of the convertible regime appear to be much weaker than for the others, although one could argue that the much greater instances of supply shocks in these countries may in part account for the greater use of discretionary policy.

Across country groupings, the difference between the 'expanded core' of countries and the periphery observed in Tables 3 to 5 is also apparent. Under the gold standard regime most of these countries had substantially lower supply and demand shocks than the others. This can be seen in the comparison between the G-11 aggregate and the aggregate of all countries except the G-11. The pattern also holds up in both post-World War II regimes.

In sum, the evidence on demand and supply shocks complements the preceding evidence in Tables 3 to 5 . For the 'expanded core' countries, represented roughly by the G-11, the gold standard was 
characterized by higher demand and especially higher supply shocks than in the post-World War Il regimes, and within the post war period both the Bretton Woods regime and the float were relatively stable. $^{24}$ This evidence suggests that, for these countries, it is unlikely that the convertible regimes prevailed because of the absence of supply shocks, since the size of demand and supply shocks was quite similar across both types of regimes. The durability or fragility of past convertible regimes likely had more to do with regime design (Bordo, 1993b).

By contrast, for the peripheral countries, especially Latin America and Southern Europe, demand shocks exceeded supply shocks across all regimes, and especially under the postwar float. The constraints of the convertible regime appear to be much weaker than for the G-11, although one could argue that the much greater incidence of supply shocks in peripheral countries may in part account for the greater use of discretionary policy.

\section{Conclusion}

In conclusion, we suggest answers to three questions. First, what is the evidence for the specie standard as a contingent rule? Second, why was the rule successful when it was? Third, why did some countries successfully adhere and others did not?

Our historical survey reveals that the contingent rule over the entire period was strictly followed by a relatively small number of countries - the core countries (with the exception of France and Germany after World War I); the Anglo countries of new settlement, most of the Scandinavian and smaller western European countries, and Japan. For the rest it was violated. If we focus only on the classical gold standard period, the basic convertibility rule was followed by a larger group of countries. For Bretton Woods, the rule was much less clearly defined hence it is difficult to distinguish adherence and non adherence. For that regime clearly, as statistical evidence in Section 5 of superior performance measured by nominal variables compared to other regimes shows, convertibility was important. 
Second, the rule prevailed when it did for a number of possible reasons. The classical gold standard era was one of stable economic growth, with few impediments to the free allocation of labor, capital and goods both within and across countries. It was also a period characterized by relative political stability and, for many of the 'expanded core' countries by the absence of populist pressure for demand management (Eichengreen 1992a). In addition, it was an era characterized by the coincidence of beliefs in free trade and exchange rate stability by the dominant industrial commercial groups in different countries (Gallarotti 1993). The dominance of England as a commercial power also was important. England's clear commitment to the rule and the benefits of access to her financed markets was a key determinant of other countries adherence.

Third, the different experience of adherence to the rule by the expanded core countries and the peripheral countries may, we suggest, be explained by their different stages of economic development. By the beginning of the classical gold standard era the 'expanded core' countries were industrialized, had experienced decades of rising per capita income, had stable polities and were dominated by groups who perceived the benefits to them of monetary stability. In addition, as maturing diversified economies they were less subject to the disruptions of massive swings in the price of primary products. These conditions were absent in the peripheral countries. Faced with frequent supply shocks; for them adherence to the rule was more difficult. 


\section{References}

Abramowitz, Moses. 1973. The Monetary Side of Long Swings in U.S. Economic Growth. Stanford University Center for Research on Economic Growth. Memorandum No. 146 (mimeo) Acena, Pablo Martin. 1993. Spain During the Classical Gold Standard Years, 1880-1914. In Monetary Regimes in Transition. (eds.) Michael D. Bordo and Forrest Capie. Cambridge: Cambridge University Press.

Barro, Robert J. and David B. Gordon. 1983. Rules, Discretion and Reputation in a Model of Monetary Policy. Journal of Monetary Economics 12:101-121.

Bayoumi, Tamin and Barry Eichengreen. 1992a. Economic Performance Under Alternative Exchange Rate Regimes: Some Historical Evidence. University of California at Berkeley. June. (mimeo) Bayoumi, Tamin and Barry Eichengreen. 1992b. Is There a Conflict Between EC Enlargement and European Monetary Unification? NBER Working Paper No. 3950. January. Greek Economic Review (forthcoming)

Bayoumi, Tamin and Barry Eichengreen. 1993. Shocking Aspects of European Monetary Unification. In Adjustment and Growth in European Monetary Union. (eds.) Francesco Torres and Francesco Giavazzi. Cambridge: Cambridge University Press.

Bayoumi, Tamin and Barry Eichengreen. 1994. Monetary and Exchange Rate Arrangements for NAFTA. Journal of Development Economics 43:125-65.

Bernanke, Benjamin. 1983. Nonmonetary Effects of the Financial Crisis in the Propagation of the Great Depression. American Economic Review. 73:259-76.

Bernanke, Benjamin and Harold James. 1991. The Gold Standard, Deflation and Financial Crisis in the Great Depression: An International Comparison. In Financial Markets and Financial Crisis (ed.) R. Glenn Hubbard, Chicago: University of Chicago Press: :33-68. 
Blanchard, Olivier and Danny Quah. 1989. The Dynamic Effects of Aggregate Demand and Aggregate Supply Disturbances. American Economic Review. (September):655-73.

Bloomfield, Arthur. 1959. Monetary Policy Under the International Gold Standard, 1800-1914. New York: Federal Reserve Bank of New York.

Bordo, Michael D. 1981. The Classical Gold Standard: Some Lessons for Today. Federal Reserve Bank of St. Louis Review. 63 (May):2-17.

Bordo, Michael D. 1984. The Gold Standard: The Traditional Approach. In A Retrospective on the Classical Gold Standard, 1821-1931. (eds.) Michael D. Bordo and Anna J. Schwartz. Chicago: University of Chicago Press.

Bordo, Michael D. and Angela Redish. 1990. Credible Commitment and Exchange Rate Stability: Canada's Interwar Experience. Canadian Journal of Economics. 23(2):357-380.

Bordo, Michael D. and Finn E. Kydland. 1992. The Gold Standard As a Rule. Federal Reserve Bank of Cleveland. Working Paper No. 9205. March.

Bordo, Michael D. 1993a. The Bretton Woods International Monetary System: An Historical Overview. In A Retrospective on the Bretton Woods System: Lessons for International Monetary Reform. (eds.) Michael D. Bordo and Barry Eichengreen. Chicago: University of Chicago Press.

Bordo, Michael D. 1993b. The Gold Standard, Bretton Woods and Other Monetary Regimes: A Historical Appraisal. Federal Reserve Bank of St. Louis Review. 75-2(March/April) :123-191. Bordo, Michael D. and Lars Jonung. 1994. Monetary Regimes, Inflation and Monetary Reform: An Essay in Honor of Axel Leijonhufvud. Rutgers University Working Paper No. 94-07.

Bordo, Michael D. and Anna J. Schwartz. 1994. The Specie Standard As a Contingent Rule: Some Evidence for Core and Peripheral Countries, 1880 - 1990. Rutgers University Working Paper No. 94-11. 
Bordo, Michael D. and Eugene N. White. 1993. British and French Finance During the Napoleonic Wars. In Monetary Regimes in Transition. (eds.) Michael D. Bordo and Forrest Capie. Cambridge: Cambridge University Press.

Butlin, S.J. 1986. The Australian Monetary System 1851-1914. Sydney Australian Reserve Bank.

Calomiris, Charles W. 1988. Price and Exchange Rate Determination During the Greenback Suspension. Oxford Economic Papers. December.

Calomiris, Charles. 1993. Greenback Resumption and Silver Risk: The Economics and Politics of Monetary Regime Change in the United States, 1862-1900. In Monetary Regimes in Transition. (eds.) Michael D. Bordo and Forrest Capie. Cambridge: Cambridge University Press.

Canzoneri, Matthew. 1985. Monetary Policy Games and the Role of Private Information. American Economic Review. 75:1056-1070.

Canzoneri, Matthew B. and Dale W. Henderson. 1991. Monetary Policy in Interdependent Economies. Cambridge: Massachusetts Institute of Technology Press.

Cecchetti, Stephen G. and Georgios Karras. 1992. Sources of Output Fluctuations During the Interwar Period: Further Evidence on the Causes of the Great Depression. NBER Working Paper No. 4049. April.

Condé, Roberto Cortés. 1989. Dinero, Deuda y Crisis: Evolución Fiscal y Monetaria en la Argentina. Editorial Sudamericana, Instituto Torcuato Di Tella: Buenos Aires.

Cooper, Richard. 1982. The Gold Standard: Historical Facts and Future Prospects. Brookings Papers on Economic Activity. 1:1-45.

Davis, Lance E. and Robert A. Huttenback. 1986. Mammon and the Pursuit of Empire: The Political Economy of British Imperialism, 1860-1912. Cambridge: Cambridge University Press.

De Cecco, Marcello. 1974. Money and Empire: The International Gold Standard, 1890-1914. New Jersey: Rowman and Littlefield. 
DeKock, Gabriel and Vittorio Grilli. 1989. Endogenous Exchange Rate Regime Switches. NBER Working Paper No. 3066. August.

DeVries, Margaret G. 1976. The International Monetary Fund 1966-1971: The System Under Stress, Vol. 1: Narrative. Washington, DC: International Monetary Fund.

Edelstein, Michael. 1982. Overseas Investment in the Age of High Imperialism: The United Kingdom, 1850-1914. New York: Columbia University Press.

Eichengreen, Barry. 1985. Editor's Introduction. In The Gold Standard in Theory and History. (ed.) Barry Eichengreen. London: Methuen.

Eichengreen, Barry. 1987. Conducting the International Orchestra: Bank of England Leadership Under the Classical Gold Standard. Journal of International Money and Finance. (6):5-29.

Eichengreen, Barry. 1989. Hegemonic Stability Theories. In Can Nations Agree? (eds.) Richard Cooper et. al. Washington, DC: Brookings Institution.

Eichengreen, Barry. 1992a. The Gold Standard Since Alec Ford. In Britain in the International Economy: 1870-1939. (eds.) S.N. Broadberry and N.F.R. Crafts. Cambridge: Cambridge University Press.

Eichengreen, Barry. 1992b. Golden Fetters: The Gold Standard and the Great Depression, 1919-1939. Oxford University.

Eichengreen, Barry. 1993. Three Perspectives on the Bretton Woods System. In A Retrospective on the Bretton Woods System. (eds.) Michael. D. Bordo and Barry Eichengreen. Chicago: University of Chicago Press and NBER.

Eichengreen, Barry. 1994. International Monetary Arrangements for the 21st Century. University of California at Berkeley. (mimeo)

Eschweiler, Bernhard and Michael D. Bordo. 1993. Rules, Discretion and Central Bank Independence: The German Experience 1880-1989. NBER Working Paper No. 4547. 
Fishlow, Albert. 1987. Market Forces or Group Interests: Inconvertible Currency in Pre-1914 Latin America. University of California at Berkeley. (mimeo)

Fishlow, Albert. 1989. Conditionality and Willingness to Pay: Some Parallels from the 1989s. In The International Debt Crisis in Historical Perspective. (eds.) Barry Eichengreen and Peter Lindert. Cambridge: Massachusetts Institute of Technology Press.

Flood, Robert P. and Peter Isard. 1989. Simple Rules, Discretion and Monetary Policy. NBER Working Paper No. 2934.

Ford, A.G. 1962. The Gold Standard 1880-1914: Britain and Argentina. Oxford: Clarendon Press. Fratianni, M. and Spinelli, F. 1984. Italy in the Gold Standard Period, 1861-1914. In A Retrospective on the Classical Gold Standard, 1921-1931. Michael D. Bordo and Anna J. Schwartz. (eds.) Chicago: University of Chicago Press.

Frieden, Jeffrey A. 1993. The Dynamics of International Monetary Systems: International and Domestic Factors in the Rise, Reign, and Demise of the Classical Gold Standard. In Coping with Complexivity in the International System. Jack Snyder and Robert Jervis. (eds.) Colorado: Westview Press.

Friedman, Milton. 1990. Bimetallism Revisited. Journal of Economic Perspectives. 4(4):85-104.

Friedman, Milton and Schwartz, Anna J. 1963. A Monetary History of the United States, 1867-1960. Princeton: Princeton University Press.

Fritsch, Winston and Gustavo H.B. Franco. 1992. Aspects of the Brazilian Experience Under the Gold Standard. PUC Rio de Janeiro. (mimeo)

Gallarotti, Giulio, M. 1993. The Scramble for Gold: Monetary Regime Transformation in the 1870s. In Michael D. Bordo and Forrest Capie (eds.) Monetary Regimes in Transition, Cambridge: Cambridge Univerity Press. 
Giovannini, Alberto. 1989. How Do Fixed Exchange-Rate Regimes Work: The Evidence From the Gold Standard, Bretton Woods and the EMS. In Blueprints for Exchange Rate Management. (eds.) Marvin Miller, Barry Eichengreen and Richard Portes. London: Center for Economic Policy Research. : 13-46.

Giovannini, Alberto. 1993. Bretton Woods and Its Precursors: Rules Versus Discretion in the History of International Monetary Regimes. In A Retrospective on the Bretton Woods System. (eds.) Michael D. Bordo and Barry Eichengreen. Chicago: University of Chicago Press.

Grilli, Vittorio. 1990. Managing Exchange Rate Crises: Evidence from the 1890's. Journal of International Money and Finance. 9:258-275.

Grossman, Herschel J. and John B. Van Huyck. 1988. Sovereign Debt as a Contingent Claim: Excusable Default, Repudiation, and Reputation. American Economic Review. 78:1088-1097.

Haavisto, Tarmo. 1992. Money and Economic Activity in Finland 1866-1985. Lund, Sweden. Lund Economic Studies.

Hayashi, Fumio: 1989. Japan's Saving Rate: New Data and Reflections. NBER Working Paper No 3205 .

Horsefield, Keith. 1969. The International Monetary Fund, 1945-1965: Twenty Years of International Monetary Co-operation, Vol. I, Chronicle. Washington, DC: International Monetary Fund.

Jonung, Lars. 1984. Swedisn Experience Under the Classical Gold Standard, 1873-1914. In A Retrospective on the Classical Gold Standard, 1821-1931. Michael D. Bordo and Anna J. Schwartz. (eds.) Chicago: University of Chicago Press.

Keating, John W. and John V. Nye. 1991. Permanent and Transitory Shocks in Real Output: Estimates from Nineteenth Century and Postwar Economies. St. Louis: Washington University Working Paper No. 160 . 
Keynes, John Maynard. [1930] 1971. The Applied Theory of Money: A Treatise on Money, Vol. 6 of The Collected Writings of John Maynard Keynes. Reprint London: MacMillan and New York: Cambridge University Press for the Royal Economic Society.

Krugman, Paul. 1991. Target Zones and Exchange Rate Dynamics. Quarterly Journal of Economics. $56: 669-682$.

Kydland, Finn E. and Prescott, Edward. 1977. Rules Rather than Discretion: The Inconsistency of Optimal Plans. Journal of Political Economy. 85:473-491.

Lazaretou, Sophia. 1994. Government Spending, Monetary Policies and Exchange Rate Regime Switches: The Drachma in the Gold Standard Period. Explorations in Economic History, October. (forthcoming)

Lindert. Peter. 1969. Key Currencies and Gold, 1900-1913. Princeton Studies in International Finance, No. 24. Princeton: Princeton University Press.

Llona-Rodriguez, Augustine. 1993. Chile During the Gold Standard: A Successful Paper Money Experieace. Instiruto Torcuato Di Tella. (mimeo)

Lucas, Robert E. Jr. and Nancy L. Stokey. 1983. Optimal Fiscal and Monetary Policy in an Economy Without Capital. Journal of Monetary Economics. 12:(1)55-93.

Mankiw, Gregory. 1987. The Optimal Collection of Seigniorage--Theory and Evidence. Journal of Monetary Economics. 20:(2)327-41.

McKinnon, Ronald I. 1988. An International Gold Standard Without Gold. Cato Journal. 8(Fall):351373

McKinnon, Ronald I. 1993. International Money in Historical Perspective. Journal of Economic Literature. $31(1): 1-44$. 
Meltzer, Allan H. and Saranna Robinson. 1989. Stability Under the Gold Standard in Practice. In Monetary, History and International Finance: Essays in Honor of Anna J. Schwartz. (ed.) Michael D. Bordo. Chicago: University of Chicago Press. :163-195.

Miller, Marcus and Alan Sutherland. 1992. Britain's Return to Gold and Entry into the ERM. In Exchange Rate Targets and Currency Banks. (eds.) Paul Krugman and Marcus Miller Cambridge: Cambridge University Press.

Miller, Marcus and Alan Sutherland. 1994. Speculative Anticipations of Sterling's Return to Gold: Was Keynes Wrong? Economic Journal. July.

Mitchell, Brian R. 1992. International Historical Statistics: Europe 1750-1988. New York: Stockton Press.

Obstfeld, Maurice. 1992. Destabilizing Effects of Exchange Rate Escape Clauses. NBER Working Paper No. 3606.

Officer, Lawrence. 1986. The Efficiency of the Dollar-Sterling Gold Standard, 1980-1908. Journal of Political Economy. 94(October):1038-1073.

Officer, Lawrence. 1993. Gold-Point Arbitrage and Uncovered Interest Arbitrage Under the 1925-1931 Dollar-Sterling Gold Standard. Explorations in Economic History. 30(1):98-127.

Pelaez, Carlos M. and Wilson Suzigan. 1976. Historia Monetaria do Brazil. Editoria Universidade de Brazilia.

Reis, Jaime. 1992. The Gold Standard in Portugal, 1854-1891. Universidale Nova de Lisbon. (mimeo) Roll, Richard. 1972. Interest Rates and Price Expectations During the Civil War. Journal of Economic History, 32(June):476-498.

Schwartz, Anna J. 1984. Introduction. In A Retrospective on the Classical Gold Standard, 1821-1931. (eds.) Michael D. Bordo and Anna J. Schwartz. Chicago: University of Chicago Press.

Sharkey, R. D. 1959. Money, Class, and Party. Baitimore: Johns Hopkins Press. 
Shearer, Ronald A. and Carolyn Clark. 1984. Canada and the Interwar Gold Standard, 1920-1935: Monetary Policy Without a Central Bank. In A Retrospective on the Classical Gold Standard 1821-1931. (eds.) Michael D. Bordo and Anna J. Schwartz. Chicago: University of Chicago Press.

Shinjo, Hiroshi. 1962. History of the Yen. Research Institute for Economics and Business Administration. Japan: Kobe University.

Simons, Henry C. 1951. Rules Versus Authorities in Monetary Policy. In A.E.A. Readings in Monetary Theory. (ed.) Richard D. Irwin. Homewood, Illinois.

Smith, Gregor and Todd Smith. 1993. Wesley Mitchell and Irving Fisher and the Greenback Gold Reforms 1865-1879. Queens University. (mimeo)

Smith, W. S. and Smith, R.T. 1990. Stochastic Process Switching and the Return to Gold. Economic Joumal. 100(March): 164-175.

Stiglitz, Joseph and Andrew Weiss. 1981. Credit Rationing in Markets with Imperfect Information. American Economic Review. 71(6):393-410.

Svennson, Lars E. O. 1994. Why Exchange Rate Bands? Monetary Independence In Spite of Fixed Exchange Rates. Journal of Monetary Economics. 33(1):157-199.

Unger, 1. 1964. The Greenback Era: A Social and Political History of American Finance, 1865-1879. New Jersey: Princeton University Press.

Yeager, Leland B. 1984. The Image of the Gold Standard. In A Retrospective on the Classical Gold Standard, 1821-1931. (eds.) Michael D. Bordo and Anna J. Schwartz. Chicago: University of Chicago Press. 
</ref_section> 
*For able research assistance we would like to thank Alexandre Hohmann. For supplying us with data and valuable information we are indebted to the following: Pablo Martin Acena, Lance Davis, Marc Flandreau, Lars Jonung, Sophie Lazaretou, Augustin Llona Rodriguez, Gerardo della Paollera, David Pope, Angela Redish, Jaime Reis, Georg Rich, Fernando Santos. The usual disclaimer holds.

\section{Endnotes}

1. The Currency School in England in the early nineteenth century made the case for the Bank of England's fiduciary note issue to vary automatically with the level of the Bank's gold reserve (the currency principle). Following such a rule was viewed as preferable (for providing price-level stability) to allowing the note issue to be altered at the discretion of the well-meaning and possibly well-informed directors of the Bank (the position taken by the opposing Banking School). For a discussion of the Currency Banking School debate, see Viner (1937), Fetter (1965), and Schwartz (1987).

2. Viewed, however, as a rule in the traditional sense - as an automatic mechanism to ensure price stability - bimetallism may have had greater scope for automaticity than the gold standard because of the additional cushion of a switch from one metal to the other. See Friedman (1990).

3. This description is consistent with a result from a model of Lucas and Stokey (1983), in which financing of wars is a contingency rule that is optimal. In their example, where the occurrence and duration of the war are uncertain, the optimal plan for the debt is not to service it during the war. Under this policy, people realize when they purchase the debt it that effectively it will be defaulted on in the event the war continues.

4. A case study comparing British and French finances during the Napoleonic Wars shows that Britain was able to finance its wartime expenditures by a combination of taxes, debt, and paper money issue-to smooth revenue; whereas France had to rely primarily on taxation. France had to rely on a less efficient mix of finance than Britain because she had used up her credibility by defaulting on outstanding debt at the end of the American Revolutionary War and by hyperinflating during the Revolution. Napoleon ultimately returned France to the bimetallic standard in 1803 as part of a policy to restore fiscal probity, but because of the previous loss of reputation France was unable to take advantage of the contingent aspect of the bimetallic standard rule. See Bordo and White (1993).

5. The behavior of asset prices (exchange rates and interest rates) during suspension periods suggests that market agents viewed the commitment to gold as credible. For the U.S. see Roll (1972) and Calomiris (1988), who present evidence of expected appreciation of the greenback during the American Civil War based on a negative interest differential between bonds that were paid in greenbacks and those paid in gold. Also, see Smith and Smith (1993) who demonstrate that movements in the premium on gold from the Resumption Act of 1875 until resumption was established in 1878 were driven by a credible belief that resumption would occur. For the case of Britain's return to gold in 1925, see Smith and Smith (1990), Miller and Sutherland (1992) and (1994). An application of the stochastic process switching literature suggests that the increasing likelihood that resumption would occur at the original parity gradually altered the path of the dollar-pound exchange rate towards the new ceiling, several months in advance. 
6. For suggestive evidence see Bordo and Kydland (1992).

7. Also see Officer (1993). His calculations of speculative bands (bands within which uncovered interest arbitrage prevails consistent with gold point arbitrage efficiency) for the interwar dollar sterling exchange rate show serious violations only in 1931, at the very end of the gold exchange standard.

8. A case study of Canada during the Great Depression provides evidence for the importance of the credible commitment mechanism of adherence to gold. Canada suspended the gold standard in 1929 but did not allow the Canadian dollar to depreciate nor the price level to rise for two years. Canada did not take advantage of the suspension to emerge from the depression because of concern for its credibility with foreign lenders. See Bordo and Redish (1990).

9. Eschweiler and Bordo (1993) provide evidence for this interpretation for Germany over the period 1883 - 1913 based on an estimation of the Reichsbank's reaction function. They find that the central bank's pursuit of an interest rate smoothing policy (an obvious violation of 'the rules of the game') was subordinate to its commitment to keep the exchange rate within the gold points.

10. The U.S. could change the dollar price of gold if a majority of members (and every member with $10 \%$ or more of the total quotas) agreed.

11. Indeed, Giovannini's (1993) calculations show that during the Bretton Woods convertible period credibility bounds on interest rates for the major currencies, in contrast to the classical gold standard, were frequently violated.

12. In 1869 institutions to supply capital to new firms and industries by issuing notes convertible into government notes were established in 8 commercial cities, of which only the one that issued notes convertible into silver coin found public acceptance.

13. Despite the monetary disarray, the Meiji government succeeded in floating two foreign loans in London in 1871 and 1873 , the first for 1 million pounds at $9 \%$, for construction of a railroad between Tokyo and Yokohama, the second for 3.4 million pounds at $7 \%$, to pay pensions to feudal lords and soldiers, the feudal clans having been abolished in 1870 by the new national government. During the same years, England, France, and Russia sold their bonds in Japan, paid for by gold exports from Japan.

14. Although Chile's experience of borrowing funds in sterling at prevailing rates in a period when the currency was inconvertible does not seem to support this statement (see Llona-Rodriguez, 1993, n. 9).

15. Use of capital calls on the new securities issued is superior to the new foreign lending series used in earlier studies (e.g. Edelstein, 1982). This is because the capital calls give the amount of funds actually available to send to the receiving countries, whereas the new foreign lending series represents the face value of the bonds. The amounts actually available were only a fraction of the total issue which the investors committed themselves to provide over a period of years during which calls were made (see Davis and Huttenback, 1986, ch.1).

16. A real series deflated by the British Sauerbeck-Statist wholesale price index is very similar to the current dollar series presented here.

17. For earlier applications of similar regime comparisons in a different context see Bordo (1993a), (1993b) and Bordo and Jonung (1994). 
18. In Bordo and Schwanz (1994) we also present data for real per capita growth, and the absolute rates of change of nominal and real exchange rates.

19. Both variables were rendered stationary by first differencing.

20. Specifically, four restrictions are placed on the matrix of the shocks: two are simple normalizations, which define the variances of the shocks to aggregate demand and aggregate supply; the third assumes that demand and supply shocks are orhogorial; the fourh is that demand shocks have only temporary effects on output, i.e., that the cumulative effect of demand shocks on the rate of change in output must be zero.

21. See Keating and Nye (1991).

22. The results for most country groupings in the interwar period figures are similar to those reported for the U.S. by Cecchetti and Karras (1992), who estimate a three-variable VAR with monthly data. The late 1920's and early 1930's reveal a major negative demand shock consistent with Friedman and Schwartz's (1963) attribution of the onset of the Great Depression to monetary forces. After 1931, negative supply shocks predominate, consistent with Bernanke's (1983) and Bernanke and James' (1991) explanation for the severity of the Great Depression that stresses the collapse of the financial system.

23. The rankings by regime for the weighted average of individual country shocks are similar to the group aggregates.

24. These results are very similar to those presented for the G-7 in Bordo (1993b) and by Eichengreen and Bayoumi (1992a). 
TABLE 1 A. PRE-BRETTON WOODS

DATES OF SPECIE CONVERTIBILITY AND SUSPENSIONS

POI 21 COUNTRIES IN SEVEN GROUPINGS

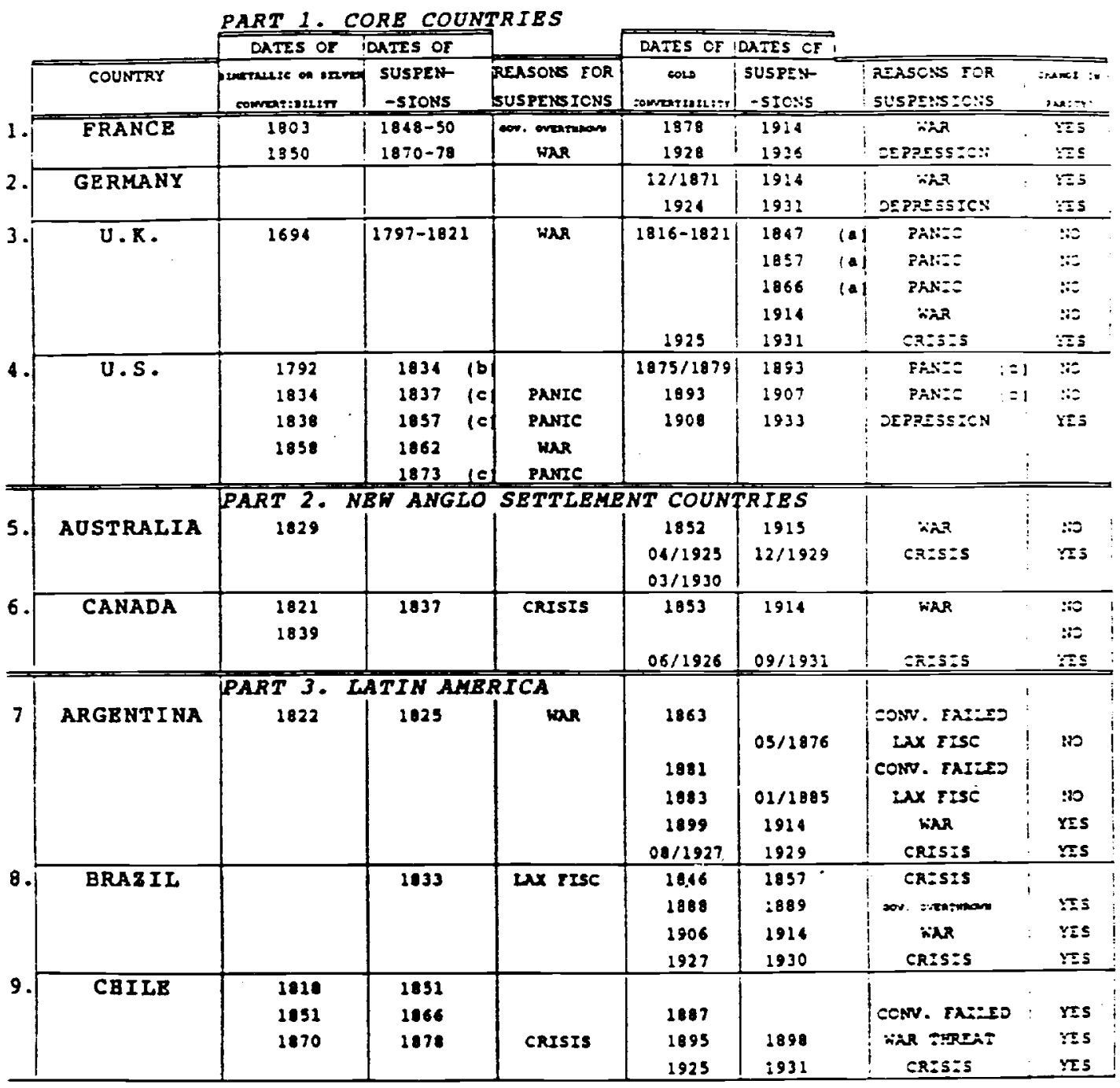

(a) suspension of Banking Act of 1844

(b) change in mint ratio

(c) restriction of payments by banks 
TABLE 1 A. PRE-BRETTON WOODS CONTINUED

DATES OF SPECIE CONVERTIBILITY AND SUSPENSIONS FOE 21 COUNTRIES IN SEVEN GROUPINGS

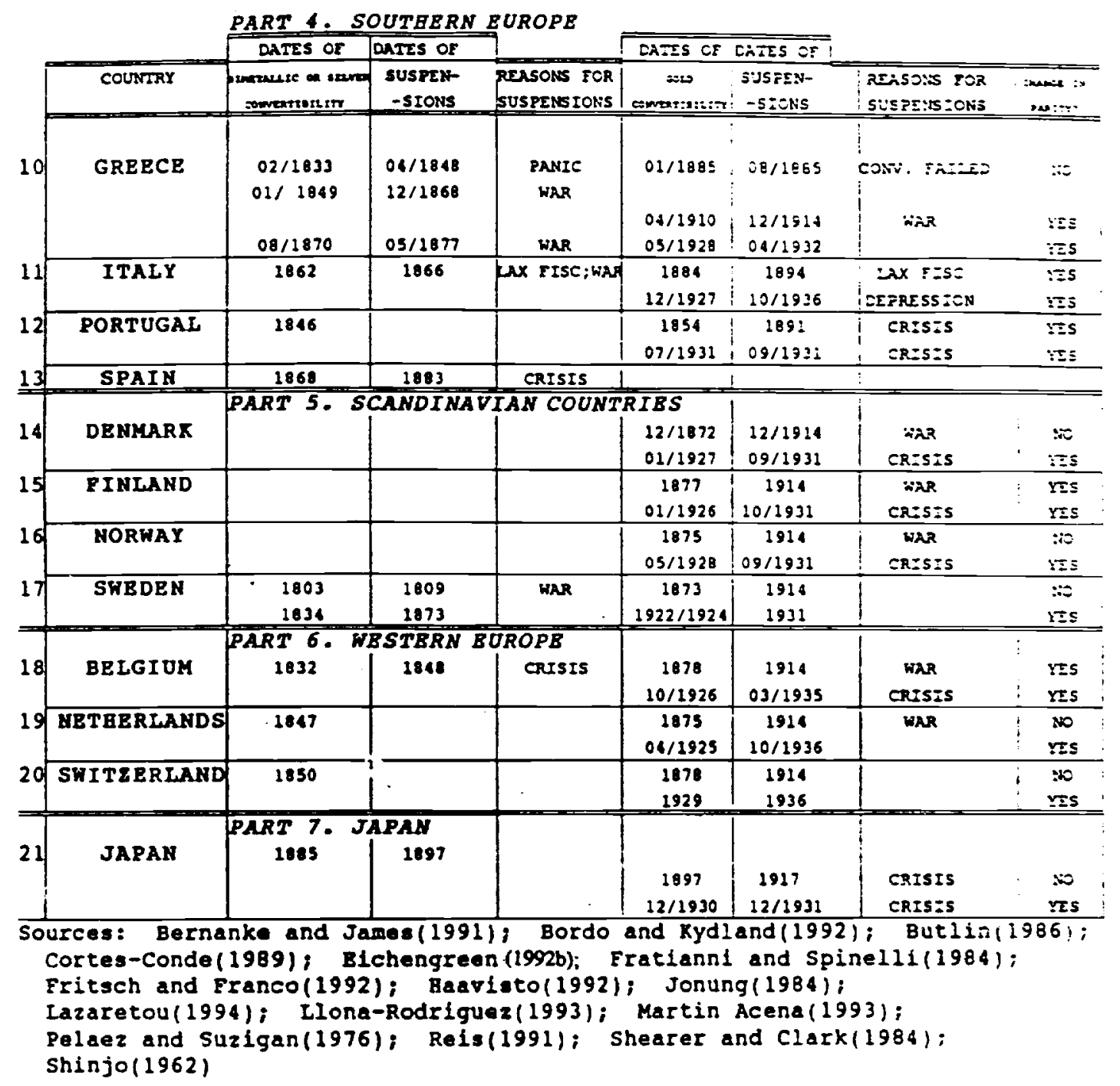


TABLZ 1 B. BRETTON WOODS 1946 TO 1971

DATES OF PAR VALUES, SUSPRNSIONS, AND PAR CHANGES

POR 21 COUNTRIES IN SEVEN GROUPINGS

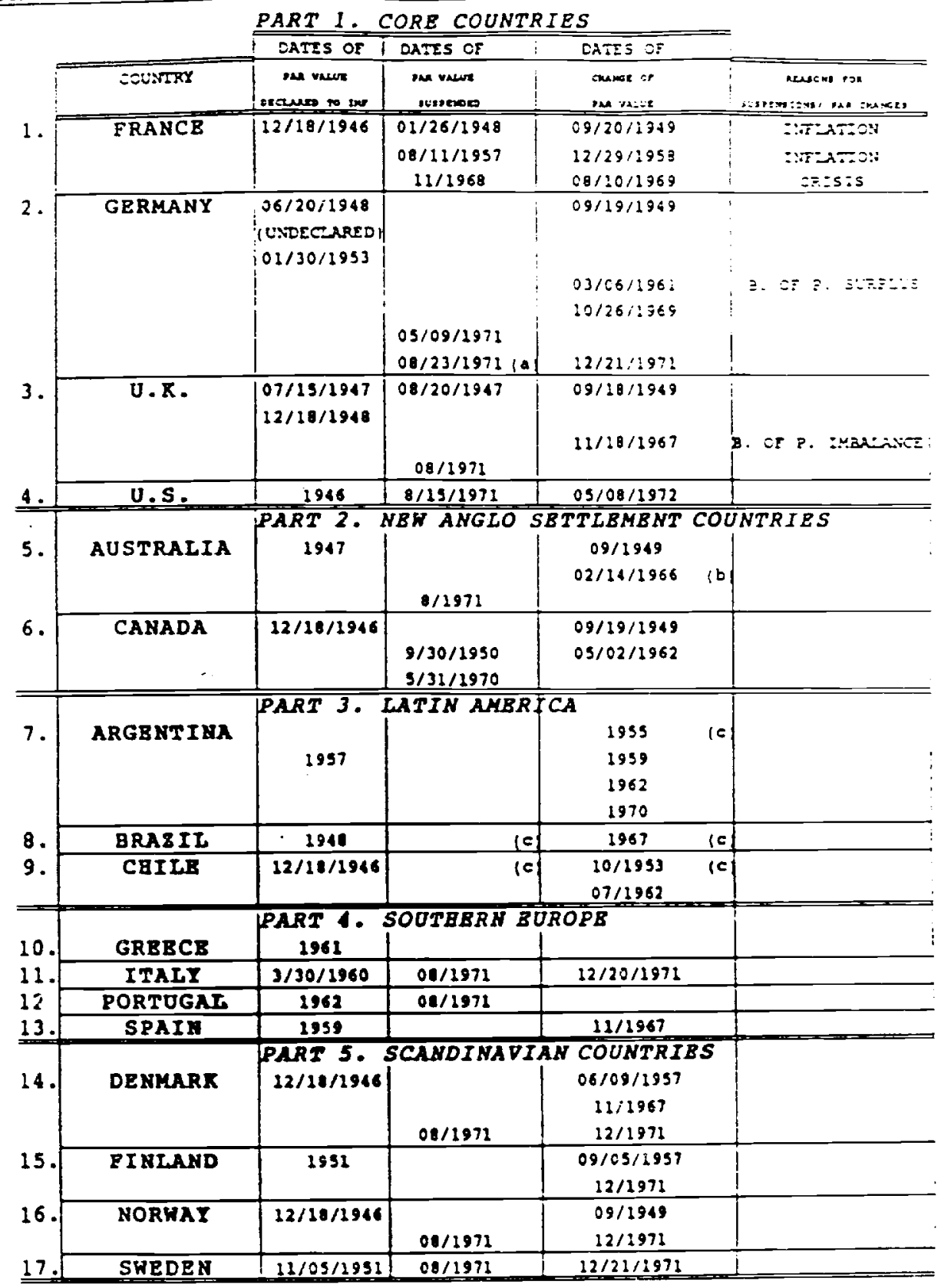


TABLE 1 B. BRETTON WOODS 1946 TO 1971 CONTINURD

DATES OF PAR VALUES, SUSPENSIONS, AND PAR CEANGES

FOR 21 COUNTRIES IN SEVEN GROUPINGS

PART I. CORB COUNTRIES

\begin{tabular}{|c|c|c|c|c|c|}
\hline & EATES of & DATES OF & EATES OF & \multirow{2}{*}{ 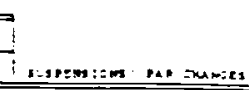 } \\
\hline & & 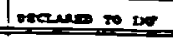 & suennomen & ma verer & \\
\hline & & 'PART 6. & BSTERN E & $P E$ & \\
\hline \multirow[t]{2}{*}{18.} & BELGIUM & 1946 & $08 / 1971$ & $09 / 21 / 2949$ & \\
\hline & & & & $12 / 21 / 1971$ & \\
\hline \multirow[t]{3}{*}{19.} & NETBERLANDS & 1946 & & $09 / 22 / 1949$ & \\
\hline & & & & $03 / 07 / 2961$ & \\
\hline & & & $05 / 09 / 1971$ & $12 / 21 / 1971$ & \\
\hline \multirow{3}{*}{20.1} & \multicolumn{3}{|c|}{ SHITZERLANDF MOT A MIMBER } & & 1 \\
\hline & \multicolumn{3}{|c|}{ PART 7. JAPAN } & & \\
\hline & JAPAN & $04 / 25 / 1949$ & $08 / 1971$ & $12 / 21 / 1971$ & \\
\hline
\end{tabular}

(a) DUNA EXchunat Rates

(b) CHANGE TROM AUSTRACLAN POUND TO AUSTRALIAN DOLLAR

(c) MULIFLC EXchuse RATLS

Sources: Bordo(19932); DeVrles(1976); Horsefield(1969) 

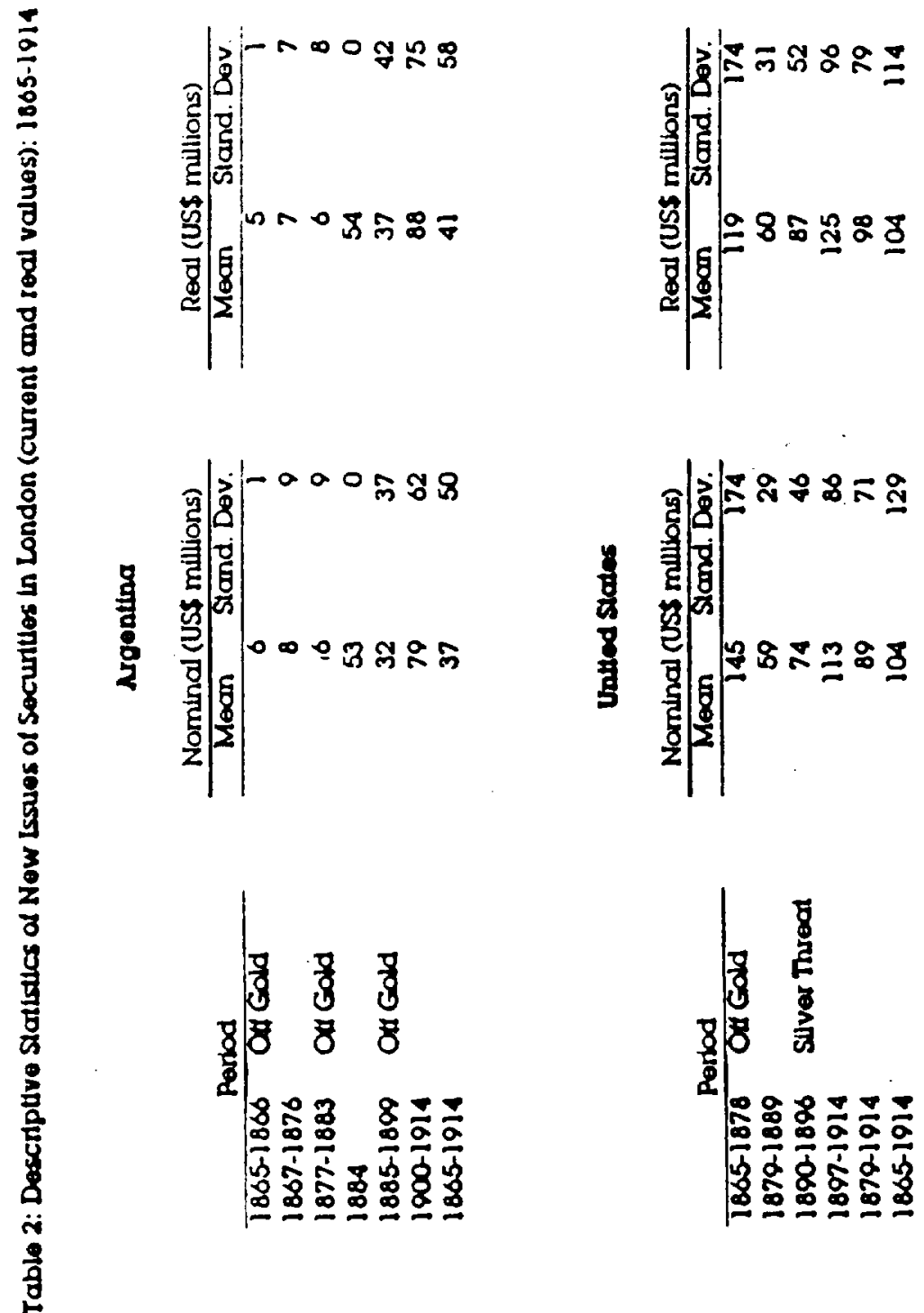

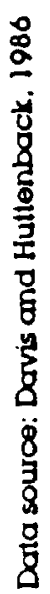


rablo 31 Descriptive statigtics of solected Open Econoer variables, 21 Cougtries $2381-1590:$ Inflation. Annual batas Means and standard Deviationat

\begin{tabular}{|c|c|c|c|c|c|c|c|c|}
\hline \multirow{2}{*}{$\begin{array}{l}\text { a) Core countries } \\
\text { United states } \\
\text { United Kingdom } \\
\text { Germany } \\
\text { rrance }\end{array}$} & \multicolumn{2}{|c|}{$\begin{array}{l}\text { Gold seandard } \\
(1881-1913)\end{array}$} & \multicolumn{2}{|c|}{$\begin{array}{l}\text { Interwar } \\
(1919-1938)\end{array}$} & \multicolumn{2}{|c|}{$\begin{array}{l}\text { Bretton } \\
\text { Woods } \\
(1946-1970)\end{array}$} & \multicolumn{2}{|c|}{$\begin{array}{l}\text { Fioating } \\
\text { Excriange } \\
(1974-1990)\end{array}$} \\
\hline & $\begin{array}{l}0.3 \\
0.3 \\
0.6 \\
0.0\end{array}$ & $\begin{array}{l}3.1 \\
3.1 \\
2.6 \\
4.8\end{array}$ & $\begin{array}{r}-1.8 \\
-1.5 \\
-2.1 \\
2.2\end{array}$ & $\begin{array}{l}7.6 \\
7.8 \\
4.7 \\
9.2\end{array}$ & $\begin{array}{l}2.4 \\
3.9 \\
2.7 \\
5.6\end{array}$ & $\begin{array}{l}2.6 \\
2.2 \\
4.0 \\
4.1\end{array}$ & $\begin{array}{l}5.6 \\
9.4 \\
3.3 \\
8.8\end{array}$ & $\begin{array}{l}2.4 \\
6.1 \\
1.2 \\
3.2\end{array}$ \\
\hline mean & 0.3 & 3.4 & -0.8 & 7.3 & 3.6 & 3.2 & 6.0 & 3.2 \\
\hline
\end{tabular}

b) Anglo-saxon Countries of Now sett lement

Australia

Canada

mean

c) Latin America

Argentina
Brazli
Chile

mean

d) Southern Europe

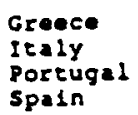

spain

mean

-) Scandinarla

Denmark

Norway

Sweden

mean

f) other Western Europe

Belglum
Netherlands
swhtzerlind
mean
g) Japan
h) N11 countries
l) 211 except 4
core countries
k) N11 + switzerland
Switzerlend

$\begin{array}{rrrrrrrr}0.5 & 3.9 & 0.3 & 5.7 & 5.1 & 4.9 & 10.0 & 3.0 \\ 0.4 & 1.4 & -1.9 & 6.1 & 2.7 & 3.0 & 7.3 & 2.6 \\ 0.5 & 2.6 & -0.8 & 5.9 & 3.9 & 4.0 & 1.6 & 2.8\end{array}$

$\begin{array}{rrrrrrrr}2.6 & 14.2 & -1.7 & 6.3 & 22.9 & 14.7 & 122.9 & 77.0 \\ 4.3 & 17.5 & 3.0 & 6.3 & 24.3 & 14.8 & 94.5 & 87.0 \\ 5.2 & 9.1 & 5.5 & 7.3 & 27.7 & 13.0 & 30.9 & 4.2 .2 \\ 4.0 & 13.6 & 2.3 & 6.6 & 25.0 & 14.2 & 82.8 & 58.4\end{array}$

$\begin{array}{rrrrrrrr}n n & n a & 1.8 & 3.4 & 7.8 & 9.7 & 15.9 & 3.2 \\ 0.6 & 3.2 & -1.1 & 11.7 & 3.8 & 12.5 & 12.9 & 4.6 \\ 0.6 & 3.5 & 7.9 & 15.4 & 2.2 & 3.2 & 17.4 & 3.6 \\ -0.2 & 1.2 & -0.7 & 7.3 & 8.6 & 5.8 & 12.6 & 4.5 \\ 0.3 & 2.6 & 2.0 & 10.0 & 5.6 & 7.5 & 14.7 & 4.0\end{array}$

0.32 .6

2.010 .0

$\begin{array}{rr}-2.6 & 7.6 \\ 4.6 & 10.8 \\ -3.1 & 9.7 \\ -2.3 & 6.1\end{array}$

$\begin{array}{rr}3.5 & 5.4 \\ 9.1 & 10.2\end{array}$

$3.7 \quad 3.9$

$\begin{array}{ll}7.4 & 3.2 \\ 3.0 & 3.8\end{array}$

$\begin{array}{ll}7.6 & 3.6 \\ 8.4 & 3.0\end{array}$

$-0.68 .5$

5.05 .9

8.23 .4

\begin{tabular}{|c|c|c|c|c|c|c|c|}
\hline $\begin{array}{l}0.2 \\
1.0 \\
n\end{array}$ & $\begin{array}{l}4.9 \\
2.2 \\
n a\end{array}$ & $\begin{array}{r}3.8 \\
-3.1 \\
-2.2\end{array}$ & $\begin{array}{l}4.4 \\
5.6 \\
4.3\end{array}$ & $\begin{array}{l}2.4 \\
4.2 \\
2.8\end{array}$ & $\begin{array}{l}3.2 \\
3.1 \\
1.9\end{array}$ & $\begin{array}{l}4.9 \\
3.6 \\
3.5\end{array}$ & $\begin{array}{l}2.5 \\
2.9 \\
1.8\end{array}$ \\
\hline 0.6 & 3.6 & -0.5 & 4.6 & 3.1 & 2.7 & 4.0 & 2.4 \\
\hline 4.6 & 5.5 & -2.7 & 7.3 & 4.5 & 4.6 & 2.6 & 2.4 \\
\hline 2.2 & 4.9 & 0.2 & 7.4 & 7.3 & 6.2 & 19.0 & 22.5 \\
\hline 1.4 & 5.3 & 0.4 & 7.5 & B. 2 & 6.9 & 21.9 & 14.7 \\
\hline 0.8 & 3.4 & -1.1 & 6.8 & 3.5 & 4.0 & 6.4 & 3.0 \\
\hline 1.6 & 6.3 & 1.4 & 8.2 & 11.2 & 8.4 & 32.6 & 22.5 \\
\hline
\end{tabular}

wean growth rate calculated as the time coeficlent from a regrestion of the netrie

netural logarlehm of endix to Bordo and schwartz (1994). 
Iable ts Descriptive statlatics of selected Open zconong variables, 21 countries 1881-1990: money Orowtb. Annual Datal Meane and Standard Deviations

$\begin{array}{cccc}\text { Gold standard } & \text { Interwar } & \text { Bretton } & \text { rLoting } \\ (1881-1913) & (1919-1938) & \text { Woods } & \text { Extiange } \\ (1946-1970) & (1974-1990)\end{array}$

a) core countries

$\begin{array}{rrrrrrrr}6.1 & 4.1 & 0.6 & 8.6 & 6.3 & 5.8 & 8.6 & 2.4 \\ 2.1 & 1.7 & 0.8 & 4.7 & 3.2 & 3.2 & 13.5 & 5.5 \\ 5.7 & 4.7 & 1.3 & 10.1 & 12.8 & 5.9 & 5.7 & 4.5 \\ 2.1 & 4.7 & 6.4 & 8.5 & 11.5 & 7.5 & 8.8 & 3.4 \\ 4.0 & 3.8 & 2.3 & 8.0 & 8.5 & 5.6 & 9.2 & 4.0\end{array}$

b) Anglo-saxon countries of New settlement

Austral is

Canada

mean

c) Latin America

Argentina
Brazil
Chile
mean

d) southern Europe

Greece
Italy
Portugal
Spain
mean
-) Scandinavia
Denmark
Finland
Norway
Sweden
mean

f) Other Western Europe

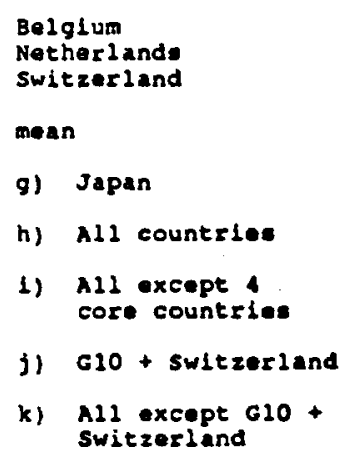

$$
\begin{array}{ll}
3.5 & 5.8 \\
7.4 & 5.3 \\
5.4 & 5.5
\end{array}
$$

$\begin{array}{rr}6.7 & 12.1 \\ 6.9 & 25.8 \\ -3.7 & 9.7\end{array}$

3.315 .9

$\begin{array}{rr}4.4 & 14.4 \\ 3.2 & 3.1 \\ 0.7 & 2.8 \\ 1.6 & 6.5 \\ 2.5 & 6.7\end{array}$

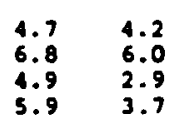

5.64 .2

$\begin{array}{ll}n a & \begin{array}{l}n a \\ 4.2\end{array} \\ n a & \begin{array}{l}3.5 \\ 4.2\end{array} \\ 7.5 \\ 4.2 & 14.5 \\ 4.3 & 7.0 \\ 4.9 & 5.0 \\ 3.5 & 7.9\end{array}$

6.

1.3

6.5
4.7

5.6

1.25 .6

5.8

6.7
4.0

5.3

9.7
10.6

4.0
3.9

10.24 .0

\section{8}

$\begin{array}{ll}1.8 & 8.9 \\ 9.2 & 12.4 \\ 5.1 & 15 .\end{array}$

8.9 22.

5.422 .1$$
\begin{aligned}
& 22.2 \\
& 32.6 \\
& 29.7
\end{aligned}
$$

28.2

$\begin{array}{rrr}10.1 & 124.6 & 82.6 \\ 21.5 & 91.5 & 79.8\end{array}$

$\begin{array}{lll}12.8 & 32.2 & 39.3\end{array}$

24.8

82.8 67.2

$\begin{array}{rrrrrr}n a & n a & 12.1 & 4.6 & 17.0 & 2.3 \\ 3.6 & 6.2 & 13.3 & 7.8 & 13.4 & 4.9 \\ 14.2 & 13.1 & 5.8 & 5.9 & 14.6 & 5.7 \\ 2.0 & 4.4 & 11.9 & 4.7 & 13.4 & 4.8 \\ 6.6 & 7.9 & 10.8 & 5.7 & 14.6 & 4.7\end{array}$

10.

$\begin{array}{rrrrrr}-0.4 & 4.8 & 6.1 & 4.1 & 11.8 & 5.5 \\ 6.3 & 7.0 & 11.8 & 5.2 & 13.3 & 4.0 \\ -1.6 & 5.6 & 5.8 & 3.6 & 12.1 & 3.4 \\ -0.8 & 4.9 & 7.1 & 3.5 & 8.6 & 4.8 \\ 0.9 & 5.6 & 7.7 & 4.1 & 12.4 & 4.4\end{array}$

(2)

'Notes and Sourcest see Table 3 


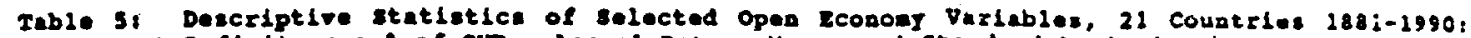
coveranent Deflelt as a of omp. Annuel Datat keans and standard Deviatlone'

\begin{tabular}{|c|c|c|c|c|c|c|c|c|}
\hline \multirow{2}{*}{$\begin{array}{l}\text { a) core countriea } \\
\text { United statea } \\
\text { United Kingdom } \\
\text { Germany } \\
\text { France }\end{array}$} & \multicolumn{2}{|c|}{$\begin{array}{l}\text { Gold standard } \\
(1881-1913)\end{array}$} & \multicolumn{2}{|c|}{$\begin{array}{l}\text { Interwar } \\
(1919-1938)\end{array}$} & \multicolumn{2}{|c|}{$\begin{array}{l}\text { Bretton } \\
\text { Woods } \\
(1946-1970)\end{array}$} & \multicolumn{2}{|c|}{$\begin{array}{l}\text { Floating } \\
\text { Exchange } \\
(2974-1990)\end{array}$} \\
\hline & $\begin{array}{r}-0.3 \\
0.1 \\
2.8 \\
0.6\end{array}$ & $\begin{array}{l}0.6 \\
0.8 \\
1.0 \\
1.1\end{array}$ & $\begin{array}{r}1.9 \\
-0.7 \\
1.4 \\
3.8\end{array}$ & $\begin{array}{l}4.4 \\
1.7 \\
1.1 \\
3.8\end{array}$ & $\begin{array}{r}-0.1 \\
-2.3 \\
0.1 \\
2.2\end{array}$ & $\begin{array}{l}2.1 \\
2.8 \\
1.8 \\
2.3\end{array}$ & $\begin{array}{l}3.0 \\
2.2 \\
1.5 \\
1.5\end{array}$ & $\begin{array}{l}1.5 \\
1.6 \\
0.8 \\
1.3\end{array}$ \\
\hline man & 0.8 & 0.9 & 1.6 & 2.8 & 0.0 & 2.3 & 2.1 & 1.3 \\
\hline
\end{tabular}

b) Anglo-saxon countries of Hew settlement

Rustradia
Canada
mean
c) Latin America

$\begin{array}{rrrrrrrr}15.1 & 2.1 & 12.6 & 2.2 & 5.0 & 2.4 & 1.4 & 0.3 \\ 0.5 & 1.1 & 1.5 & 2.5 & -1.1 & 1.7 & 2.9 & 2.0 \\ 7.8 & 1.6 & 7.1 & 2.4 & 2.0 & 2.1 & 2.2 & 1.2\end{array}$

Argentina

Brazll
Chile

$\operatorname{mean}$

d) southern Europe

Greace
rtaly
Portugal
spain

man

-) scandinavia

Denmark
Finland
Norway
Swoden

men

f) Other Weetern Europe

\begin{tabular}{|c|c|}
\hline \multicolumn{2}{|c|}{$\begin{array}{l}\text { Belgius } \\
\text { Netherlands } \\
\text { Swltzerland }\end{array}$} \\
\hline met & \\
\hline 9) & Japan \\
\hline h) & All countrles \\
\hline 1) & $\begin{array}{l}\text { A11 except } \\
\text { core countries }\end{array}$ \\
\hline j & 610 + Switzerland \\
\hline k) & $\begin{array}{l}\text { All except G10 + } \\
\text { swlezerland }\end{array}$ \\
\hline
\end{tabular}

$\begin{array}{ll}2.5 & 2.0 \\ 2.4 & 2.4\end{array}$

$2.3 \quad 3.1$

$\begin{array}{rr}n .2 & n a \\ 0.9 & 1.2 \\ 1.2 & 0.7 \\ -0.2 & 0.4 \\ 0.6 & 0.7\end{array}$

$0.6 \quad 0.7$

$\begin{array}{ll}0.5 & 1.2 \\ 0.1 & 0.1 \\ 0.6 & 0.7 \\ 0.0 & 0.6\end{array}$

$0.3 \quad 0.7$

$\begin{array}{cl}n a & \text { na } \\ 2.1 & 0.3 \\ n e & n a \\ 2.1 & 0.3 \\ -3.1 & 3.3 \\ 1.5 & 1.4 \\ 1.8 & 1.5 \\ 0.4 & 1.1 \\ 2.7 & 1.6\end{array}$

2.62 .1 $\begin{array}{llll}6.0 & 3.7 & 9.3 & 6.8 \\ 1.5 & 1.3 & 3.3 & 5.8 \\ 1.9 & 1.6 & 1.2 & 2.9\end{array}$

$3.1 \quad 2.2 \quad 5.3 \quad 5.2$

Wores and Sources: See Table 3 
Iablo 6t Supply (Paranent) and Donand (Iomporary) shocks 21 Countrioe $1881-1990$. Annual Data: standard Deviletons of shocke (V)

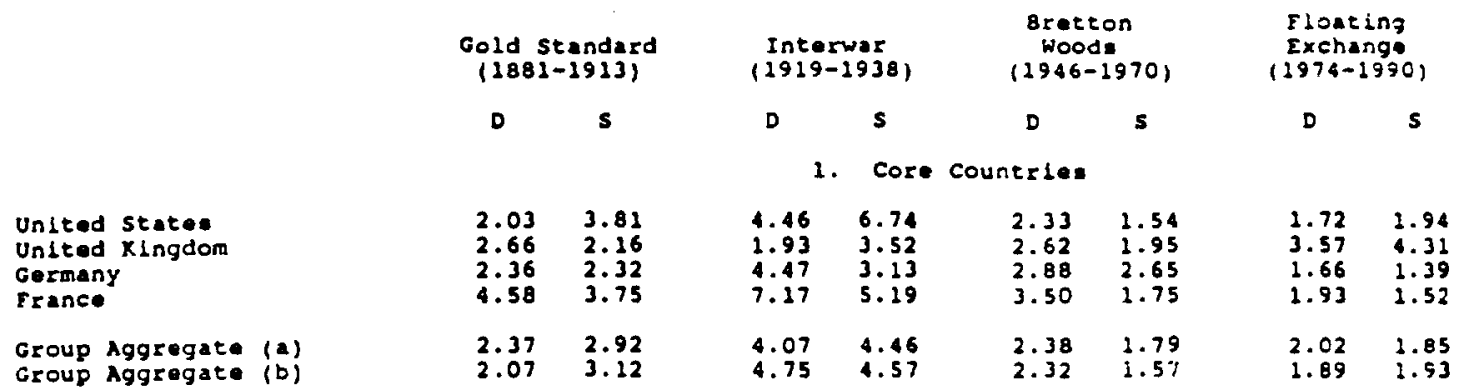

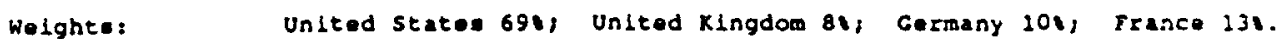

2. Anglo-saxon Countries of Now settlemene

\begin{tabular}{|c|c|c|c|c|c|c|c|c|}
\hline $\begin{array}{l}\text { Auntralla } \\
\text { Canada }\end{array}$ & $\begin{array}{l}3.92 \\
0.93\end{array}$ & $\begin{array}{l}3.97 \\
2.75\end{array}$ & $\begin{array}{l}3.37 \\
4.01\end{array}$ & $\begin{array}{l}4.02 \\
8.61\end{array}$ & $\begin{array}{l}3.73 \\
2.42\end{array}$ & $\begin{array}{l}2.48 \\
2.60\end{array}$ & $\begin{array}{l}\therefore .15 \\
2.66\end{array}$ & $\begin{array}{l}1.15 \\
2.10\end{array}$ \\
\hline $\begin{array}{l}\text { Group Aggregate (a) } \\
\text { Group Aggregate (b) }\end{array}$ & $\begin{array}{l}2.54 \\
2.24\end{array}$ & $\begin{array}{l}3.61 \\
3.27\end{array}$ & $\begin{array}{l}3.92 \\
4.08\end{array}$ & $\begin{array}{l}6.50 \\
6.71\end{array}$ & $\begin{array}{l}3.17 \\
3.01\end{array}$ & $\begin{array}{l}2.24 \\
2.65\end{array}$ & $\begin{array}{l}1.85 \\
: .89\end{array}$ & $\begin{array}{l}i .43 \\
1.57\end{array}$ \\
\hline
\end{tabular}

Welghe: Austalla 30 ; canada 70 .

3. Latin America

\begin{tabular}{|c|c|c|c|c|c|c|c|c|}
\hline $\begin{array}{l}\text { Argentina } \\
\text { Brazil } \\
\text { Chile }\end{array}$ & $\begin{array}{r}9.62 \\
15.91 \\
8.55\end{array}$ & $\begin{array}{l}6.77 \\
6.69 \\
6.90\end{array}$ & $\begin{array}{l}5.48 \\
5.76 \\
9.98\end{array}$ & $\begin{array}{l}3.67 \\
6.15 \\
9.41\end{array}$ & $\begin{array}{l}17.10 \\
16.67 \\
12.73\end{array}$ & $\begin{array}{l}4.58 \\
5.54 \\
5.62\end{array}$ & $\begin{array}{l}98.32 \\
18.16 \\
27.00\end{array}$ & $\begin{array}{l}8.42 \\
7.50 \\
8.05\end{array}$ \\
\hline $\begin{array}{l}\text { Group Aggregate (a) } \\
\text { Group Aggregate (b) }\end{array}$ & $\begin{array}{r}11.32 \\
9.32\end{array}$ & $\begin{array}{l}5.19 \\
5.81\end{array}$ & $\begin{array}{l}5.93 \\
4.86\end{array}$ & $\begin{array}{l}5.98 \\
4.72\end{array}$ & $\begin{array}{l}14.50 \\
15.20\end{array}$ & $\begin{array}{l}5.87 \\
5.25\end{array}$ & $\begin{array}{l}37.83 \\
40.01\end{array}$ & $\begin{array}{l}8.99 \\
3.68\end{array}$ \\
\hline
\end{tabular}

Argantina 34t, Braz11 564; Ch1le 104.

4. Southern Europe

\begin{tabular}{|c|c|c|c|c|c|c|c|c|c|}
\hline $\begin{array}{l}\text { Creece } \\
\text { Italy } \\
\text { Portugal } \\
\text { Spaln }\end{array}$ & & $\begin{array}{l}n a \\
3.16 \\
4.81 \\
1.09\end{array}$ & $\begin{array}{l}\text { na } \\
3.12 \\
3.77 \\
1.33\end{array}$ & $\begin{array}{l}2.27 \\
7.40 \\
5.02 \\
2.22\end{array}$ & $\begin{array}{l}2.75 \\
4.14 \\
6.46 \\
2.05\end{array}$ & $\begin{array}{l}4.02 \\
2.76 \\
2.30 \\
4.42\end{array}$ & $\begin{array}{l}3.84 \\
1.75 \\
2.20 \\
2.76\end{array}$ & $\begin{array}{l}2.37 \\
3.58 \\
2.70 \\
2.07\end{array}$ & $\begin{array}{l}1.48 \\
1.91 \\
2.26 \\
3.29\end{array}$ \\
\hline $\begin{array}{l}\text { Group Aggregate } \\
\text { Group Aggregate }\end{array}$ & (a) & $\begin{array}{l}2.89 \\
3.10\end{array}$ & $\begin{array}{l}2.47 \\
2.91\end{array}$ & $\begin{array}{r}4.07 \\
4.72\end{array}$ & $\begin{array}{l}3.56 \\
3.98\end{array}$ & $\begin{array}{l}3.57 \\
3.24\end{array}$ & $\begin{array}{l}2.36 \\
2.23\end{array}$ & $\begin{array}{l}2.81 \\
2.85\end{array}$ & $\begin{array}{l}2.52 \\
2.35\end{array}$ \\
\hline
\end{tabular}

5. Scandlnavia

\begin{tabular}{|c|c|c|c|c|c|c|c|c|}
\hline $\begin{array}{l}\text { Denmark } \\
\text { Flnland } \\
\text { Norway } \\
\text { Sweden }\end{array}$ & $\begin{array}{l}2.69 \\
2.31 \\
2.54 \\
2.57\end{array}$ & $\begin{array}{l}2.89 \\
2.26 \\
1.43 \\
3.03\end{array}$ & $\begin{array}{l}4.94 \\
3.53 \\
7.50 \\
3.08\end{array}$ & $\begin{array}{l}1.88 \\
2.91 \\
3.94 \\
5.10\end{array}$ & $\begin{array}{l}1.61 \\
7.89 \\
4.31 \\
3.89\end{array}$ & $\begin{array}{l}2.41 \\
2.21 \\
1.22 \\
2.96\end{array}$ & $\begin{array}{l}1.89 \\
1.14 \\
3.40 \\
2.32\end{array}$ & $\begin{array}{l}1.79 \\
1.18 \\
1.88 \\
2.40\end{array}$ \\
\hline $\begin{array}{l}\text { Group Aggregate (a) } \\
\text { Group Aggregate (b) }\end{array}$ & $\begin{array}{l}2.75 \\
2.52\end{array}$ & $\begin{array}{l}2.25 \\
2.50\end{array}$ & $\begin{array}{l}4.62 \\
4.36\end{array}$ & $\begin{array}{l}3.57 \\
3.74\end{array}$ & $\begin{array}{l}4.64 \\
4.27\end{array}$ & $\begin{array}{l}2.02 \\
2.28\end{array}$ & $\begin{array}{l}2.71 \\
2.53\end{array}$ & $\begin{array}{l}1.21 \\
1.95\end{array}$ \\
\hline
\end{tabular}

Welghes:

Denmark 221; Finland 159; Norway 171; Sweden 461. 


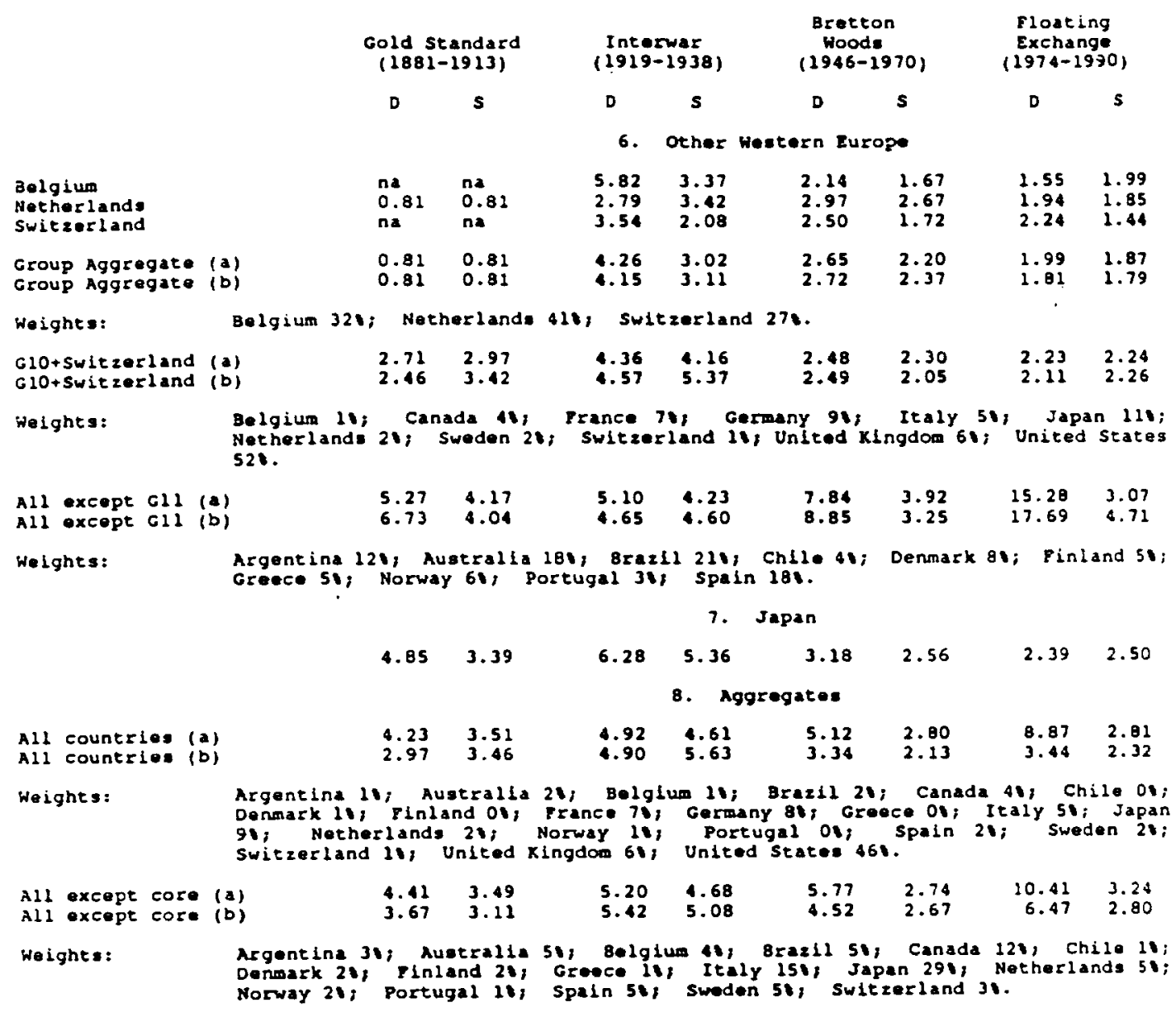

(a) Aggregate data.

Welghted dacago of individual country ohocks. The weighte are calculated as the share of Welghed the cNP data are converted to dollars using the sctual exchange rate.

Data Sources: See Data Appendix. 


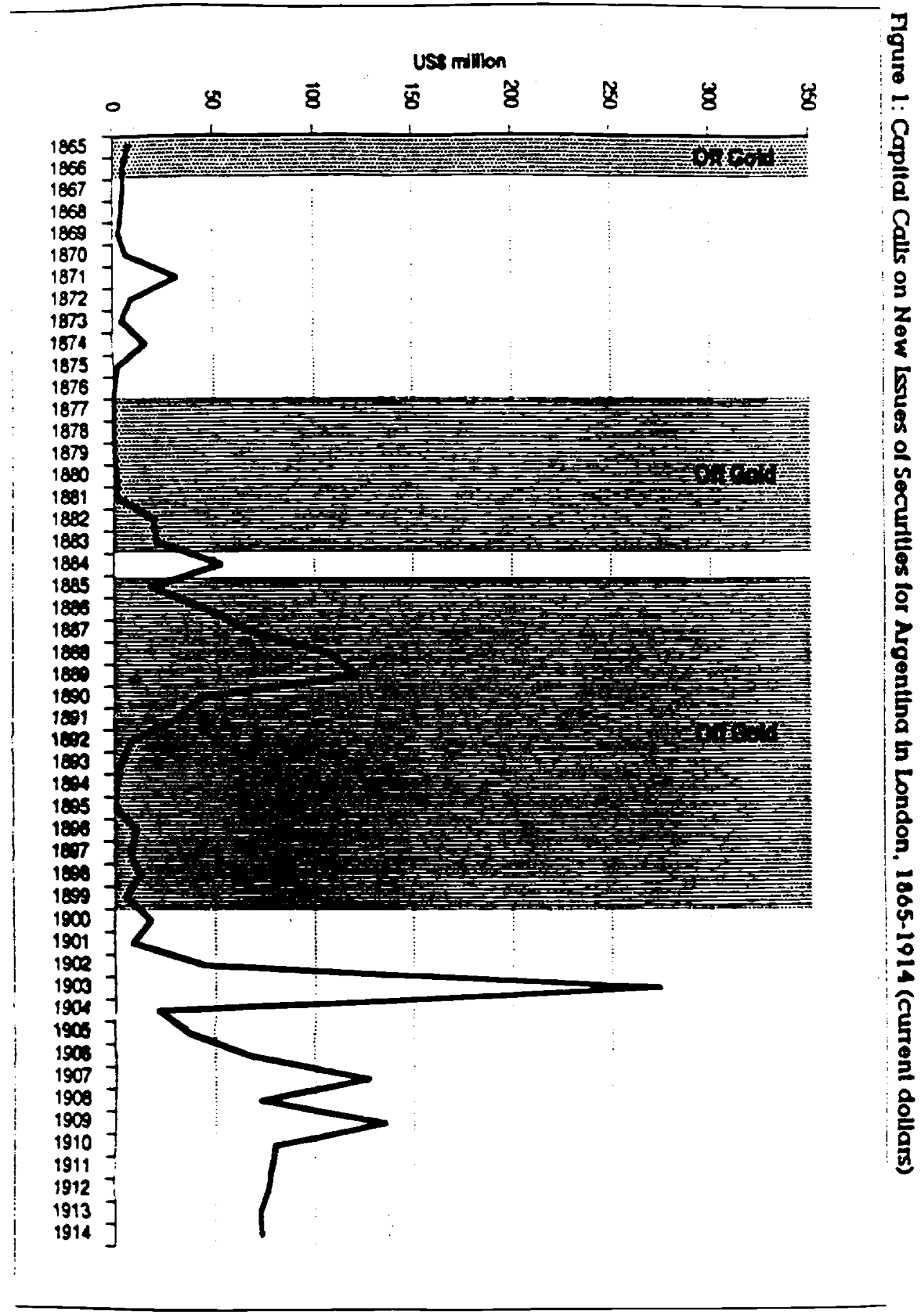




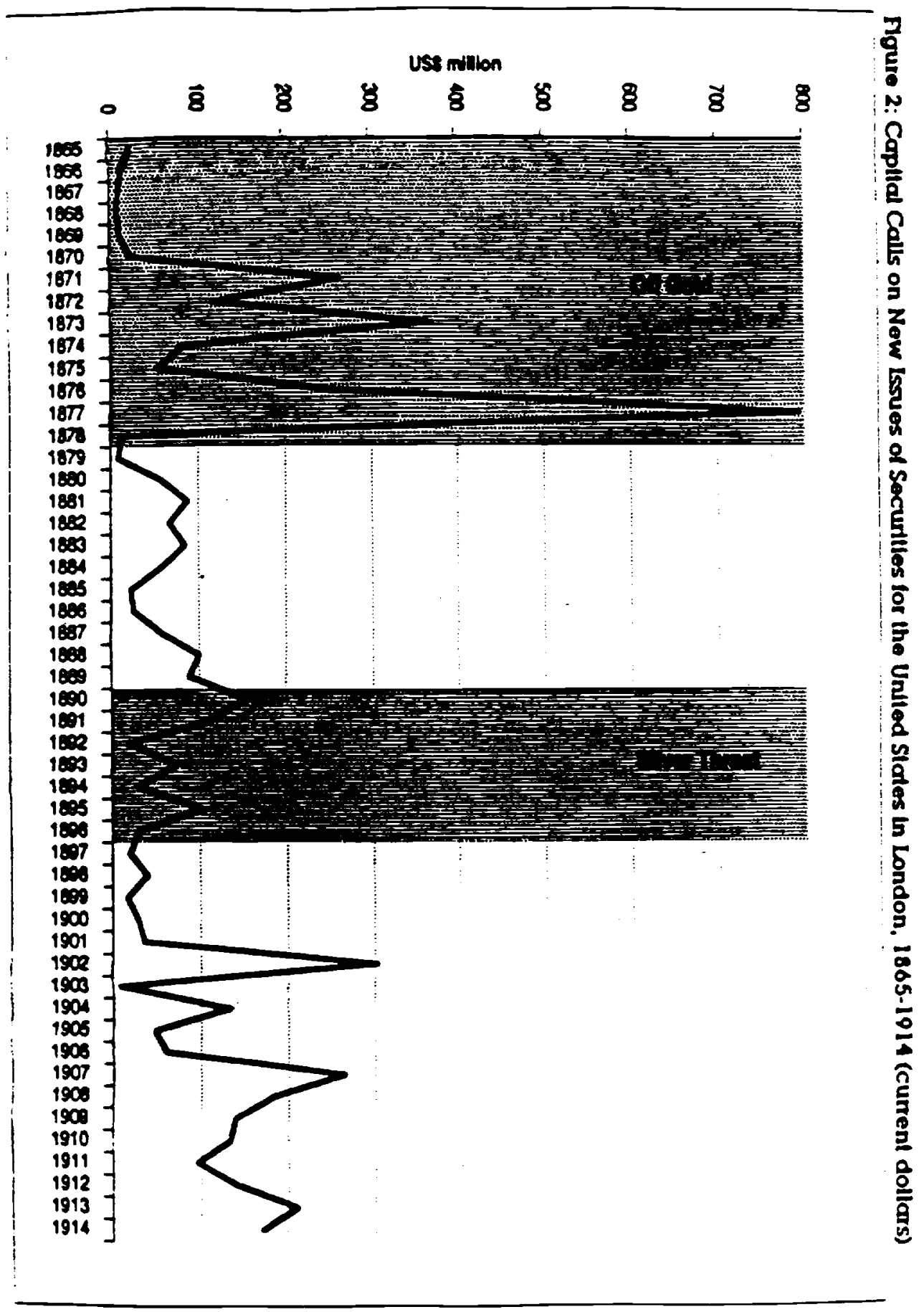


For the Gio countries plus Swltzerland, see Data Appendix in Rordo and Jonung (1994, except for the following countries:

Austraila

(1) Money. 1880-1990, Provided by David Pope. Australian National iniversty.

(2) Real GDP. 1880-1990, David Pope. (3) GDP Deflator. 1880-1790, David Pope.

(4) Exchange Rate. 1880-1990, David Pope. (5) Government Expendisureg and Revenues. 1880-1988, Dav1d Pope.

Donark

(1) Money. 1880-1990, Provided by Lara Jonung. (2) Real GDP. 1880-1990, ja:s Jonung. (3) GDP Deflator. I880-1988, B.R. M1tchell (1992). (4) Exchange Rate. 1880-1990, Lars Jonung. (5) Government Expendltures and Reverues. $1380-195 \Xi$, B.R. Mltchell (1992).

Finland

(1) Money. 1880-1990, Larg Jonung. (2) Real GDP. 1880-1990, Larg Jonung. (3) GDP Deflator. 1880-1988, B.R. MItchell (1992). (4) Exchange Rate. 2880-1990, Lars Jonung. (5) Government Expenditures and Revenues, 1880-i988, B.R. Mische:L (1992).

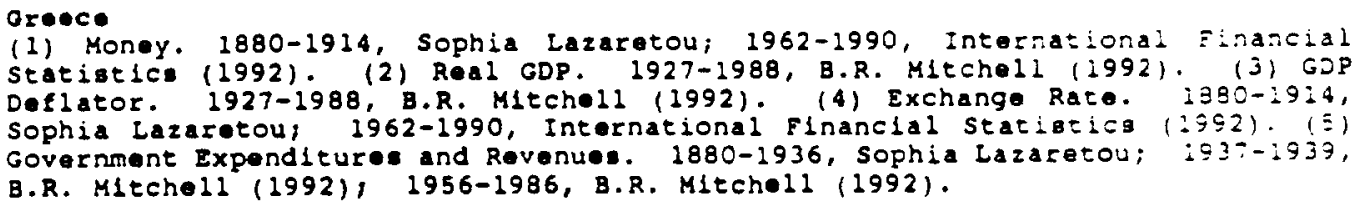

Norway

(1) Money. 1880-1990, Lare Jonung. (2) Real GDP. 1880-1990, Lars Jonung. (3) GDP Doflator: 1880-1988, B.R. Mitchell (1992). (4) Exchango Rato. $1880-1990$. Lars Jonung. (5) Government Expenditures and Ravenuea. 1880-1988, B.R. Mitche!l (1992).

Portugal

(1) Money. 1880-1990, Provlded by Fernando Santon, Universidade do Porto. (2) Real GOP. 1880-1990, Lare Jonung. (3) GDP Deflator. 1880-1988, B.R. Milcheil (1992). (4) Exchange Rate. 1890-1990, Fernando Santos. (5) Governitent Expenditures and Rerenues. 1880-1988, B.R. Mitchell (1992).

Spain

(1) Money, 1880-1980, Ietadlet1cas Historlca de Espana; 1981-1988, B.R. Mitchell (1992). (2) Roal GDP. 1901-1953, Eatadietlcas Hitorica de Espana: 1954-1988, B.R. Mitchel1 (1992). (3) GDP Deflator. 1901-1953, Eatadisticas Hitorleas de Eepanal 1954-1988, B.R. Mitchell (1992). (4) Exchange Rate. 1880-1980, Eotadisticas Historicas de Espana; 1981-1990, IES (1902). Government Expend1tures and Revenues. 1880-1988, B.R. Mitchel1 (2992). 